\title{
The Late Cretaceous belemnite family Belemnitellidae: Taxonomy and evolutionary history
}

\author{
WALTER KEGEL CHRISTENSEN
}

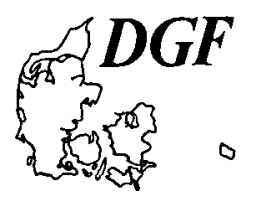

\begin{abstract}
Christensen, W. K.: The Late Cretaceous belemnite family Belemnitellidae: Taxonomy and evolutionary history. Bulletin of the Geological Society of Denmark, Vol. 44, pp. 59-88. Copenhagen, 1997-03-15. https://doi. org/10. 37570/bgsd-1998-44-04
\end{abstract}

The Late Cretaceous belemnite family Belemnitellidae Pavlow, 1914 occurs only in the Northern Hemisphere and includes nine genera and two subgenera: Praeactinocamax Naidin, 1964b, Actinocamax Miller, 1823, Belemnocamax Crick, 1910, Gonioteuthis Bayle, 1878, Belemnellocamax Naidin, 1964b, Goniocamax Naidin, 1964b, Belemnitella d'Orbigny, 1840, Belemnella (Belemnella) Nowak, 1913, Belemnella (Pachybelemnella) Schulz, 1979, Belemnella (Neobelemnella) Naidin, 1975 and Fusiteuthis Kongiel, 1962. The latter is most likely a nomen dubium. Diagnoses of the genera and subgenera are provided. The origin of the family is poorly known. The number of genera and subgenera fluctuated during the Late Cretaceous. It was one to two in the Cenomanian, increased gradually to a maximum of six in the Early Santonian, decreased gradually to one during most of the Late Campanian and increased to two or possibly three in the Maastrichtian. The belemnitellids occur in the North European and North American palaeobiogeographical Provinces of the North Temperate Realm, in additon to the northern European margin of the Tethyan Realm. The centre of evolution lay in the North European Province and all known genera and subgenera occur there. Species of five genera and two subgenera occur on the northern European margin of the Tethyan Realm and the majority of these are conspecific with species from the North European Province. Species of essentially two gen-era occur in the North American Province and these are endemic, with a few exceptions.

Key words: Belemnitellidae, taxonomy, evolutionary history, Northern Hemisphere, Late Cretaceous.

W. K. Christensen, Geological Museum, University of Copenhagen, Øster Voldgade 5-7, DK-1350 Copenhagen, Denmark; E-mail: wkc@savik.geomus.ku.dk; 3rd October 1996.

During the Late Cretaceous, except in the Cenomanian, belemnites had a bipolar distribution. The Late Cretaceous family Belemnitellidae Pavlow, 1914 inhabited the North Temperate Realm (= Boreal Realm of authors) and the late Early and Late Cretaceous (Aptian to Maastrichtian) family Dimitobelidae Whitehouse, 1924 inhabited the South Temperate Realm (= Austral Realm). The last genera of the family Belemnopseidae Naef, 1922, the mid-Cretaceous (Aptian to Cenomanian) Neohibolites Stolley, 1911 and Parahibolites Stolley, 1919 inhabited the Tethyan Realm, but occurred also in the North Temperate and South Temperate Realms, where they may be locally abundant. They became extinct in the Early and Middle Cenomanian (Combémorel, Christensen, Naidin \& Spaeth
1981). Therefore, a Tethyan Realm cannot be defined on the basis of belemnites alone after the Cenomanian, but it can be recognized on the basis of other fossil groups, such as rudists, ammonites, echinoids, actaeonellid gastropods and larger foraminifera.

The Cretaceous dimitobelids were monographed by Stevens (1965) and dealt with later by Doyle (1985, 1987a, 1987b, 1988, 1990, 1992), Doyle \& Zinsmeister (1988) and Doyle \& Howlett (1989).

The belemnitellids were distributed in the North American and North European palaeobiogeographical Provinces of the North Temperate Realm, in addition to the northern part of the Tethyan Realm in Europe (Christensen 1975a, 1976, 1988, 1993b). The centre of evolution of the belemnitellids lay in the North 
European Province, and they invaded the North American Province and Tethyan Realm at various times during the Late Cretaceous. The belemnitellids are common in the North European Province and all known genera and subgenera are recorded. They are generally rare in the North American Province, and essentially two genera are recorded. The belemnitellids occur rarely in the Tethyan Realm in Europe and five genera and two subgenera are reported.

The belemnitellids were stenothermal shelf dwellers, but it appears that the breeding, spawning, hatching, and, possibly for the females at least, dying grounds, were inner neritic, shallow water environments.

The belemnitellids are of fundamental importance in biostratigraphy and correlation in Europe, because they are common, widely distributed and their fossilization potential is high (Christensen 1990b).

The aim of this contribution is to discuss the systematic palaeontology and evolutionary history of the belemnitellids. Representative species of the genera are figured on Plates 1-2.

\section{Classification of the Belemnitellidae}

Up to 1964 , five genera within the Belemnitellidae had received general recognition by most authors, including Wright \& Wright (1951): Actinocamax Miller, 1823, Gonioteuthis Bayle, 1878, Belemnocamax Crick, 1910, Belemnitella d'Orbigny, 1840 and Belemnella Nowak, 1913. In contrast, Kongiel (1962) did not recognize Belemnella.

Naidin (1964b) proposed a new classification of the belemnitellids without a true alveolus, that is species with a convexly conical alveolar fracture, a flat anterior end or a pseudoalveolus (see below). He erected two new subgenera of Actinocamax, A. (Praeactinocamax) and A. (Paractinocamax); one new genus, Belemnellocamax; and one new subgenus of Gonioteuthis, G. (Goniocamax). He placed two small species, $A$. verus Miller, 1823 and A. laevigatus Arkhangelsky, 1912, in Actinocamax (Actinocamax); two large species, $A$. primus Arkhangelsky, 1912 and $A$. plenus (Blainville, 1825-1827), in Actinocamax (Praeactinocamax); one species, $A$. grossouvre $i$ Janet, 1891, in Actinocamax (Paractinocamax); and one species, A. mammillatus (Nilsson, 1826), in Belemnellocamax.

The following species from the North European Subprovince were placed in Gonioteuthis (Goniocamax): A. lundgreni Stolley, 1897, the type species, $A$. westfalicus (Schlüter, 1874) and A. intermedius Arkhangelsky, 1912, as well as two new species, matesovae Naidin, 1964b and medwedicicus Naidin, 1964b.A. strehlensis (Fritsch and Schlönbach, 1872), A. bohemicus Stolley, 1916 and A. paderbornensis Schlüter, 1894 were placed in the subgenus with a query. Species from the North American Province comprise A. manitobensis (Whiteaves, 1889), A. aff. plenus and A. walkeri Jeletzky, 1961. Three granulated taxa from this province: $A$. groenlandicus Birkelund, 1956, A. aff. groenlandicus and A. sternbergi Jeletzky, 1961 were placed in Gonioteuthis (Gonioca$\max$ ) with a query.

The classification of Naidin was discussed by J. A. Jeletzky in his unpublished manuscript for the Treatise on Invertebrate Palaeontology (copy obtained by me in 1972; it is referred to below as unpublished MS 1972). He placed Goniocamax in synonymy with Actinocamax (Praeactinocamax) and considered Actinocamax (Paractinocamax) as a subgenus of Belemnellocamax. Jeletzky regarded granulation to be of great taxonomic significance (see below), and in contrast to Naidin (1964b) he placed the granulated or supposedly granulated species paderbornensis, bohemicus, groenlandicus and sternbergi in Actinocamax (Actinocamax). He placed the species westfalicus, lundgreni, manitobensis and intermedius in Actinocamax (Praeactinocamax). It has been shown subsequently that paderbornensis is not granulated (Christensen 1982) and manitobensis may be granulated (Christensen \& Hoch 1983).

In this paper I recognize nine genera and two subgenera within the Belemnitellidae: Praeactinocamax Naidin, 1964b, Actinocamax Miller, 1823, Belemnocamax Crick, 1910, Gonioteuthis Bayle, 1878, Belemnellocamax Naidin, 1964b, Goniocamax Naidin, 1964b, Belemitella d'Orbigny, 1840, Belemnella (Belemnella) Nowak, 1913, Belemnella (Pachybelemnella) Schulz, 1979, Belemnella (Neobelemnella) Naidin, 1975 and Fusiteuthis Kongiel, 1962 (Fig. 1). Belemnocamax and Fusiteuthis are monotypic, but the latter is most likely a nomen dubium (see below). The classification of Naidin and his generic assignment of various species are discussed further below.

\section{Origin and evolutionary history of the Belemnitellidae}

The earliest species of the Belemnitellidae, Praeactinocamax primus, appears abruptly in the Early Cenomanian, some way above the base of the stage (Christensen 1990a). Jeletzky (1946, unpublished MS 1972) suggested that the belemnitellids are derived from Aptian belemnopseids, either Neohibolites ewaldi (Strombeck, 1861) or N. clava Stolley, 1911, because the shape of the guard and the structure of the alveolar end of these species and the earliest belemnitellids are closely similar. Doyle (1987a, 1988a, 1992) suggested that the belemnitellids may have evolved from a northern endemic stock and the dimitobelids from a southern endemic stock of the Tethyan belemnopseid Hibolithes de Montfort, 1808 during the later part of the Early Cretaceous. The sug- 
gestions by Jeletzky and Doyle suffer the disadvantage, however, that the earliest belemnitellid is separated from Neohibolites and Hibolithes, respectively, by a considerable time gap. $N$. ewaldi is middle Aptian and $N$. clava is early Late Aptian in age (Mutterlose, Schmid \& Spaeth 1983), Hibolithes became extinct in the basal Aptian in the Boreal Realm, in the middle Barremian in the Mediterranean Province and at the Hauterivian-Barremian boundary in the Indo-Pacific Province (Mutterlose 1988). The time gap between the latest belemnopseids and the earliest belemnitellid is thus at least about 20 million years (Ma).

Naidin \& Alekseev (1975) suggested that $P$. primus was derived from the early Middle Cenomanian Neohibolites repentinus Naidin \& Alekseev, 1975, which occurs in the Crimea. This suggestion was based on the similarity of the shape of the guard and the structure of the alveolar end, as well as other characters, in the two species. The suggestion by Naidin \& Alekseev is not tenable, because P. primus appears earlier than $N$. repentinus. The similarity in various characters in $P$. primus and $N$. repentinus may be a case of synchronous homeomorphy.

It can thus be concluded that the origin of the Belemnitelidae is poorly known.

Jeletzky (1946, unpublished MS 1972) further suggested that all belemnitellid genera are derived from the Cenomanian Praeactinocamax rootstock, implying that the family Belemnitellidae is a monophyletic taxon. This suggestion is, however, open to discussion. Praeactinocamax and Belemnocamax are most likely not derived from the same ancestral species

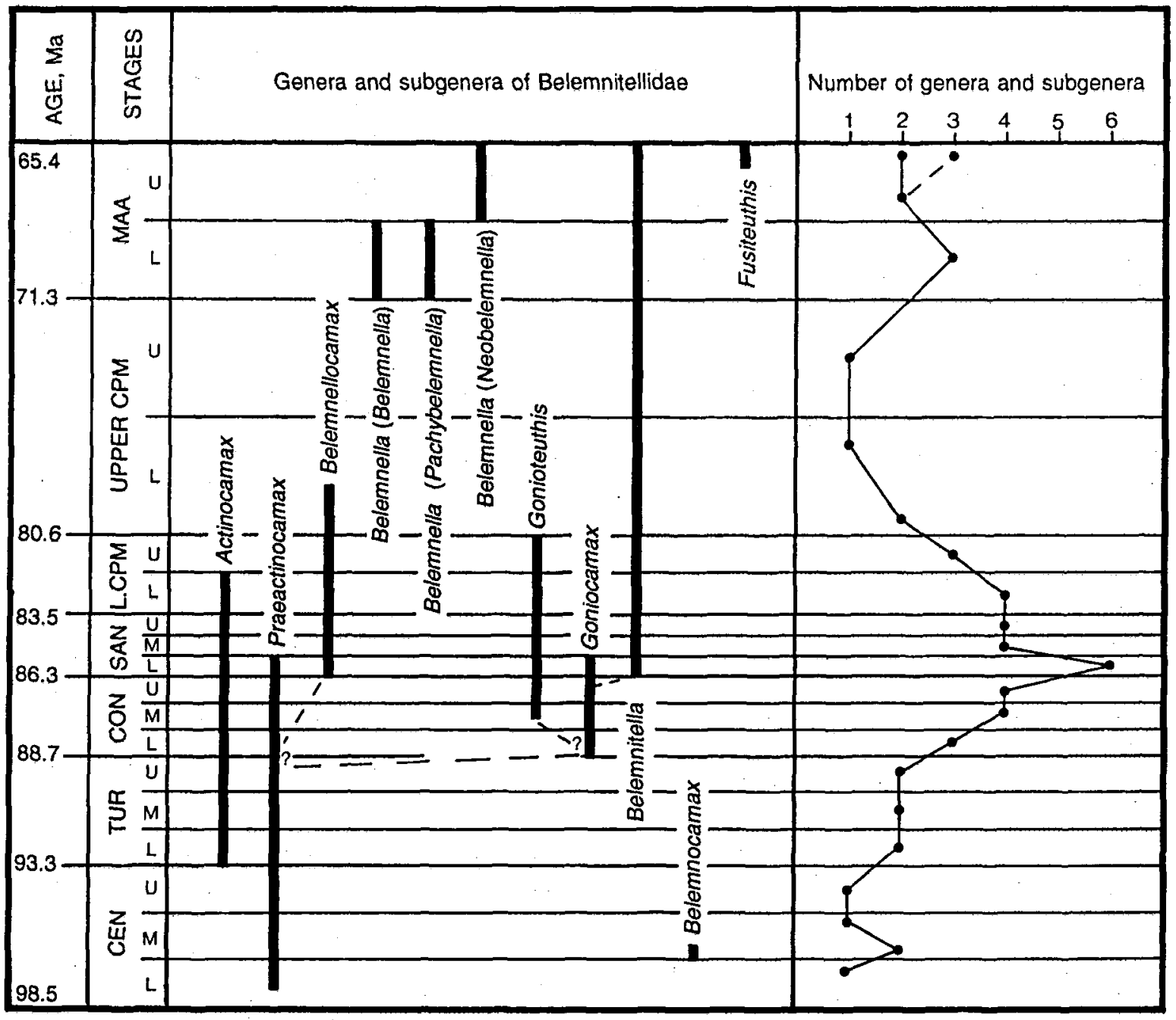

Fig. 1. Stratigraphical range and inferred phylogeny of belemnitellid genera and subgenera. Stage abbreviations after Harland et al. (1989). Ages in Ma after Obradovich (1994). 


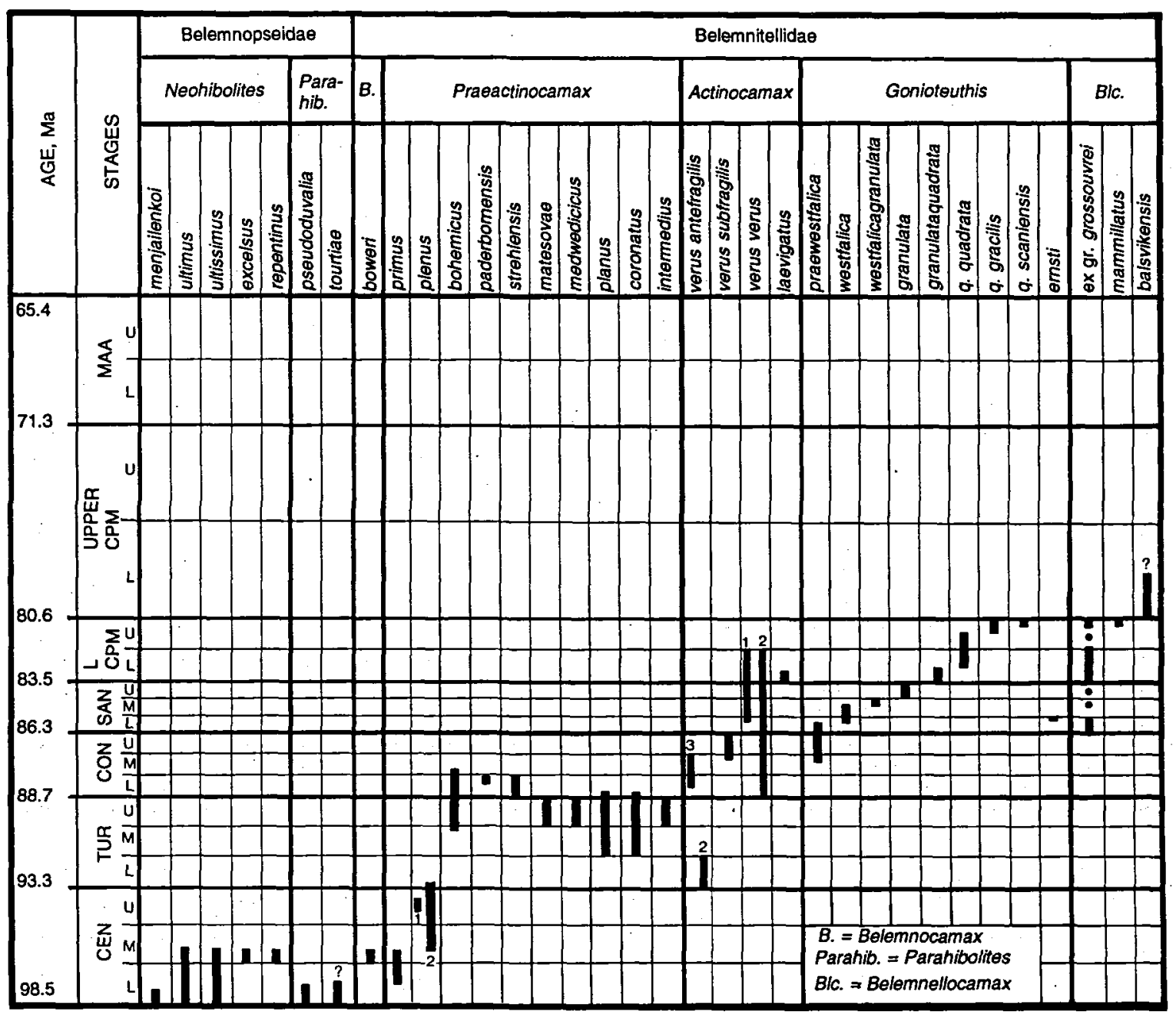

Fig. 2. Stratigraphical range diagram of Late Cretaceous belemnopseids and belemnitellids from the North European Province. 1, northwest Europe; 2, Russian Platform; 3, Bornholm, Denmark. Stage abbreviations after Harland et al. (1989). Ages in Ma after Obradovich (1994).

(Christensen 1993c). Moreover, it has been suggested by Jeletzky (unpublished MS, 1972) and Naidin (1964 b, Fig. 35) that Actinocamax, which appears in the Early Turonian (Naidin 1964b), is derived from Praeactinocamax. This suggestion is, however, very questionable, because the two genera differ in several critical characters, including the size of the guard, the length of the cone-shaped alveolar fracture, the size and shape of the juvenile guard and the growth relationship (see diagnoses). Christensen (1993b) and Christensen \& Schulz (in press) showed that growth is isometric in Actinocamax, and, consequently, both juvenile and adult specimens are short and stout. Growth is allometric in Praeactinocamax (see below); juvenile specimens are long and slender (needleshaped) and adult specimens are stouter. Thus, it seems not very likely that Actinocamax is derived from a
pre-Turonian species of Praeactinocamax, that is $P$. primus or $P$. plenus. Oddly enough, Naidin (1964b: 171) also noted that Actinocamax may be derived from a small Albian-Cenomanian species of Neohibolites. In conclusion, the Belemnitellidae is probably a polyphyletic taxon.

Goniocamax enters at the base of the Coniacian (Fig. 1) (Christensen \& Schulz, in press). Naidin (1964b) derived this genus from the Late Turonian species Gonioteuthis (Goniocamax) medwedicicus, which is here placed in Praeactinocamax (see below). Christensen (1988) suggested that the Belemnitella stock, including Goniocamax lundgreni, was derived from a Turonian-Coniacian species of Praeactinocamax from the Central Russian Subprovince. At that time, it was erroneously believed that $G$. lundgreni, the earliest species of the genus, was Late Coniacian in age. $G$. 


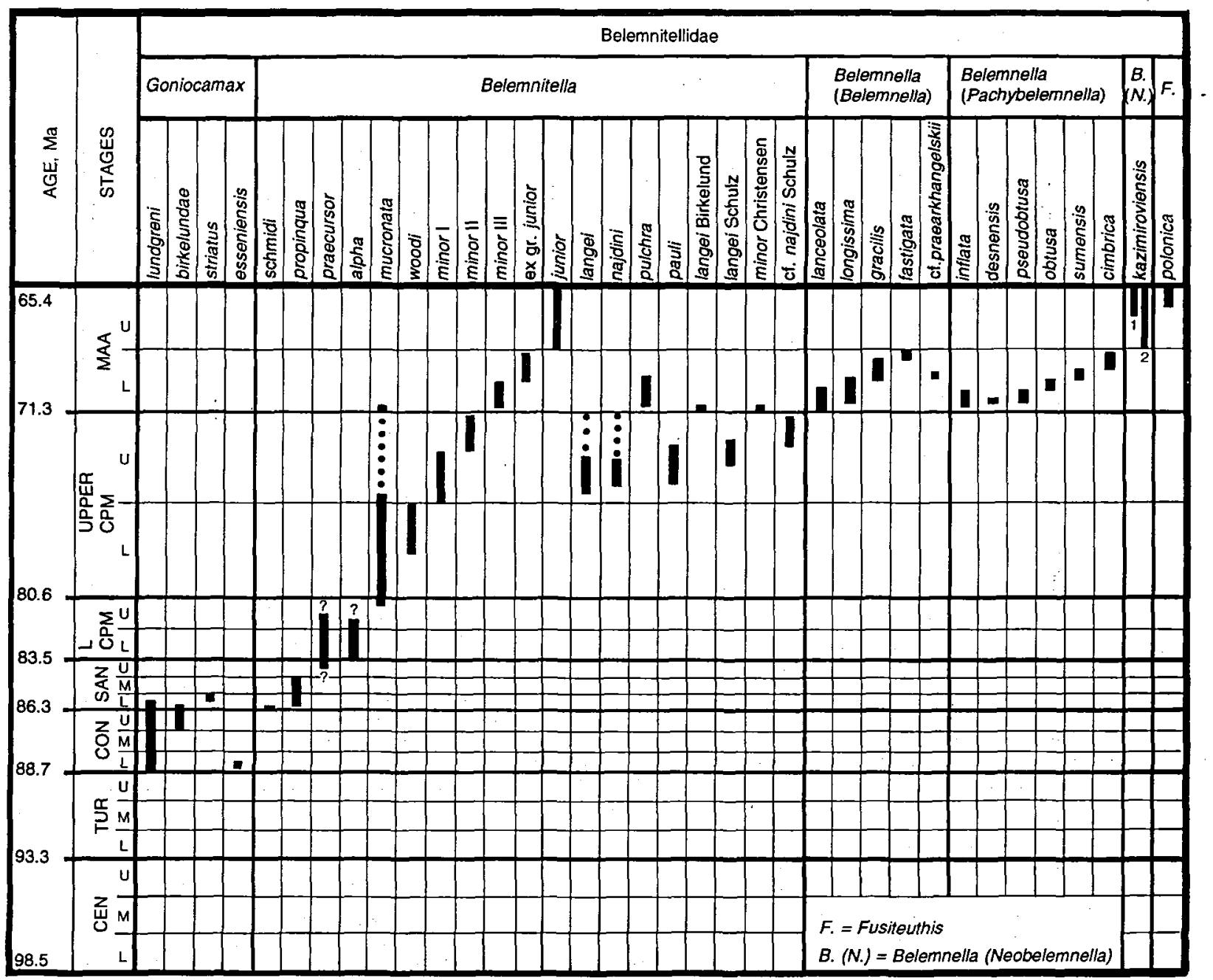

Fig. 2. Continued.

lundgreni appears, however, at the base of the Coniacian. Christensen \& Schulz (in press) noted that the origin of $G$. lundgreni is unknown.

Belemnitella appears at the base of the Santonian (Christensen \& Schulz, in press). B. schmidi Christensen \& Schulz (in press), the earliest species of the genus, may have evolved from Goniocamax lundgreni by allopatric speciation.

Gonioteuthis enters in the Middle Coniacian (Ernst \& Schulz 1974). Christensen \& Schulz (in press) suggested that the earliest species, G. praewestfalica Ernst \& Schulz, 1974, may have been derived from Goniocamax lundgreni.

Belemnellocamax appears probably at the base of the Santonian (Christensen 1986). Jeletzky (unpublished MS 1972) derived this genus from a Turonian species of Actinocamax (Praeactinocamax). Naidin (1964b) noted that the origin of the genus is unknown. Christensen (1988) suggested that Belemnellocamax may be derived from one of the large CenomanianTuronian species of Praeactinocamax from Europe due to the size of the guard, overall morphology and ontogeny. It is noteworthy, however, that the time gap between the two genera is at least $2.5 \mathrm{Ma}$.

Belemnella enters at the base of the Maastrichtian (Schulz 1979). It has been suggested that Belemnella may be derived from Belemnellocamax, because both genera have large guards, long and slender juvenile guards and a small Schatzky Distance. Furthermore, the vascular imprints branch off the dorso-lateral double furrows posteriorly at an angle exceeding 30 degrees in both genera (Nowak 1913; Jeletzky 1949a, 1951; Christensen 1975a). However, the latest species of Belemnellocamax, B. balsvikensis (Brotzen, 


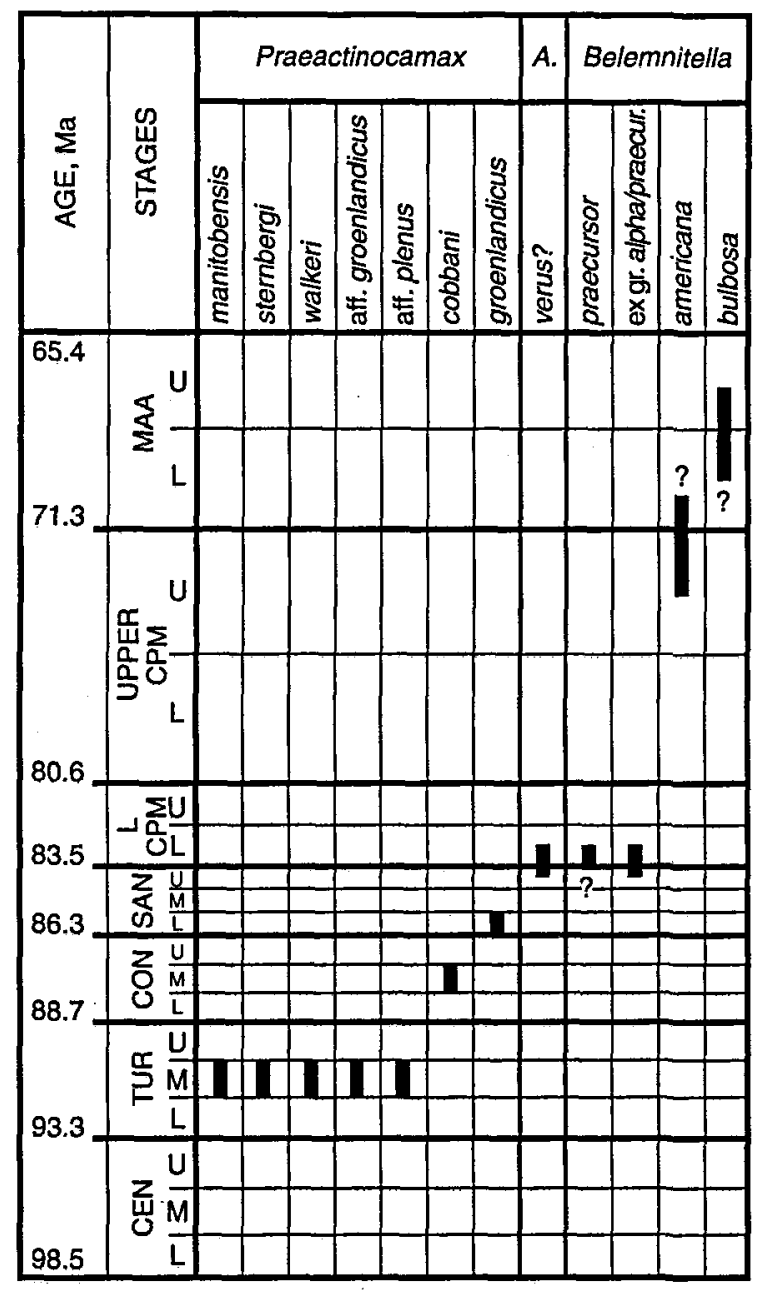

Fig. 3. Stratigraphical range diagram of Late Cretaceous belemnitellids of the North American Province. $A$. = Actinocamax. Stage abbreviations after Harland et al. (1989). Ages in Ma after Obradovich (1994).

1960), is from the early Late Campanian, and the earliest species of Belemnella, B. lanceolata (Schlotheim, 1813), is from the earliest Maastrichtian. The two genera are thus separated by a considerable time gap, estimated to be about 6-7 Ma. Schulz (1979) suggested that Belemnella may have evolved from an unknown species of Belemnellocamax or an unknown, closely allied, genus in the late Late Campanian.

Belemnocamax appears at the base of the Middle Cenomanian, has a very short age range and its origin is unknown (Christensen 1993c), Fusiteuthis enters in the latest Maastrichtian (Kongiel 1962), but is most likely a nomen dubium (discussed later).

The number of genera and subgenera of the Belemnitellidae is shown in Figure 1. One to two genera and subgenera occur in the Cenomanian and Turonian.
The number increases to three to four in the Coniacian and reaches a maximum of six in the Early Santonian. Afterwards the number decreases to four from the Middle Santonian to basal Early Campanian and three in the late Early Campanian. Only one genus, Belemnitella, occurs in the Late Campanian, except its basal part. The early Late Campanian Belemnellocamax balsvikensis occurs commonly only in Scania and is virtually absent elsewhere (see discussion below). Three genera and subgenera occur in the Early Maastrichtian and the number decreases to two or three in the Late Maastrichtian, depending the systematic status of Fusiteuthis.

Belemnitella is a very long-ranging genus, occurring from the Santonian to the Maastrichtian, c. 21 Ma longevity. The genera Actinocamax and Praeactinocamax are long-ranging, $c$. 11-12 Ma longevity. The longevity of the genera Belemnellocamax and Gonioteuthis is around 6-7 Ma. Goniocamax and the subgenera of Belemnella are short-ranging, around 2-4 Ma longevity.

The stratigraphical ranges of the belemnitellids of the North European and North American Provinces, in addition to the Tethyan Realm are shown in Figures 2-4,

\section{Systematic Palaeontology}

Class Cephalopoda Cuvier, 1795

Subclass Coleoidea Bather, 1881

Superorder Belemnoidea Hyatt, 1884

Order Belemnitida Zittel, 1895

Suborder Belemnopseina Jeletzky, 1965

Family Belemnitellidae Pavlow, 1914

[ICZN 1985, Opinion 1328, name no. 572]

Diagnosis. - Belemnopseina with a conical depression, an alveolus, in anterior part of guard, which is connected through ventral fissure with surface; surface markings consist of dorso-lateral longitudinal depressions and double furrows, single lateral furrows, more or less distinct vascular imprints, which cover all or parts of guard, longitudinal striae, and granules, which may form corrugated transverse lines; proostracum narrow and tongue-shaped, and phragmocone with a dorsal keel, which fits in a dorsal furrow in alveolus; guard prolonged ventrally around ventral fissure in a tongue-like extension; a shorter dorsal extension may also be present.

Remarks. - The guard is usually the only part of the skeleton preserved in belemnitellids, and its external and internal characters are used for taxonomic classification. These include 1) size of the guard, 2) shape of the guard, 3) structure of the adoral end, 4) surface markings, 5) internal characters, including the alveolar angle, fissure angle, Schatzky distance, and the 
shape of the bottom of the ventral fissure, and 6) ontogeny. These were discussed in detail by Christensen (1986). The Riedel-Quotient of Ernst (1964) is the ratio of the length of the guard divided by the depth of the pseudoalveolus. The Riedel-Index of Ernst \& Schulz (1974) is the depth of the pseudoalveolus as a percentage of the length of the guard. The Birkelund Index of Christensen (1995) is the length from the apex to the protoconch divided by the dorso-ventral diameter at the protoconch.

The guard is completely calcified only in the genera Belemnitella and Belemnella, and they therefore have a true alveolus adorally. However, complete guards are extremely rare, because the most anterior end is usually not preserved due to its fragility. However, Christensen $(1972,1975 a)$ figured nearly complete guards of Belemnitella mucronata (Schlotheim, 1813), B. praecursor Stolley, 1897 and B. junior Nowak, 1913 and demonstrated that the guard is prolonged ventrally in a tongue-like extension. A shorter dorsal extension may also be present; this structure should not be confused with the pro-ostracum.

In the genera Praeactinocamax, Actinocamax, Belemnocamax, Goniocamax, Gonioteuthis and Belemnellocamax the adoral part of the guard was built up of aragonite, which was lost during fossilization (Bandel \& Spaeth 1988). Therefore, the anterior end may be either conical or flat with a central pit (Praeactinocamax and Actinocamax) or developed as a pseudoalveolus (Belemnocamax, Goniocamax, Gonioteuthis and Belemnellocamax). Some species of Praeactinocamax and some specimens of Actinocamax may have a shallow pseudoalveolus.

Jeletzky $(1950,1961$, unpublished MS 1972) stressed the taxonomic importance of granulation within the belemnitellids. Christensen $(1982,1993 \mathrm{~b})$, Christensen \& Hoch (1983) and Christensen \& Schulz (in press) did not follow this point of view and showed that too much importance has been attributed to this character. Granulation may be diagnostic at the species and generic level, but it may also occur extremely rarely in genera, which are not usually granulated (see later discusion).

Jeletzky (1950) stated that all Cenomanian and most Turonian and Coniacian species of Praeactinocamax are extremely variable with respect to the shape of the guard. I disagree, because biometric studies of the Middle Cenomanian Praeactinocamax primus, the Late Cenomanian P. plenus and the Middle Coniacian P. cobbani (Christensen, 1993b) have shown that these species do not exhibit an extreme variation (Christensen 1974, 1990a, 1993b). It was shown, however, that growth was allometric. Thus, adult specimens of these species are stouter and more lanceolate in ventral view than juvenile and adolescent specimens. It is consequently very important to study the relative growth of belemnitellid species by bivariate analysis. In case of isometric growth the ratio of two variates will remain constant, whereas in case of allometric

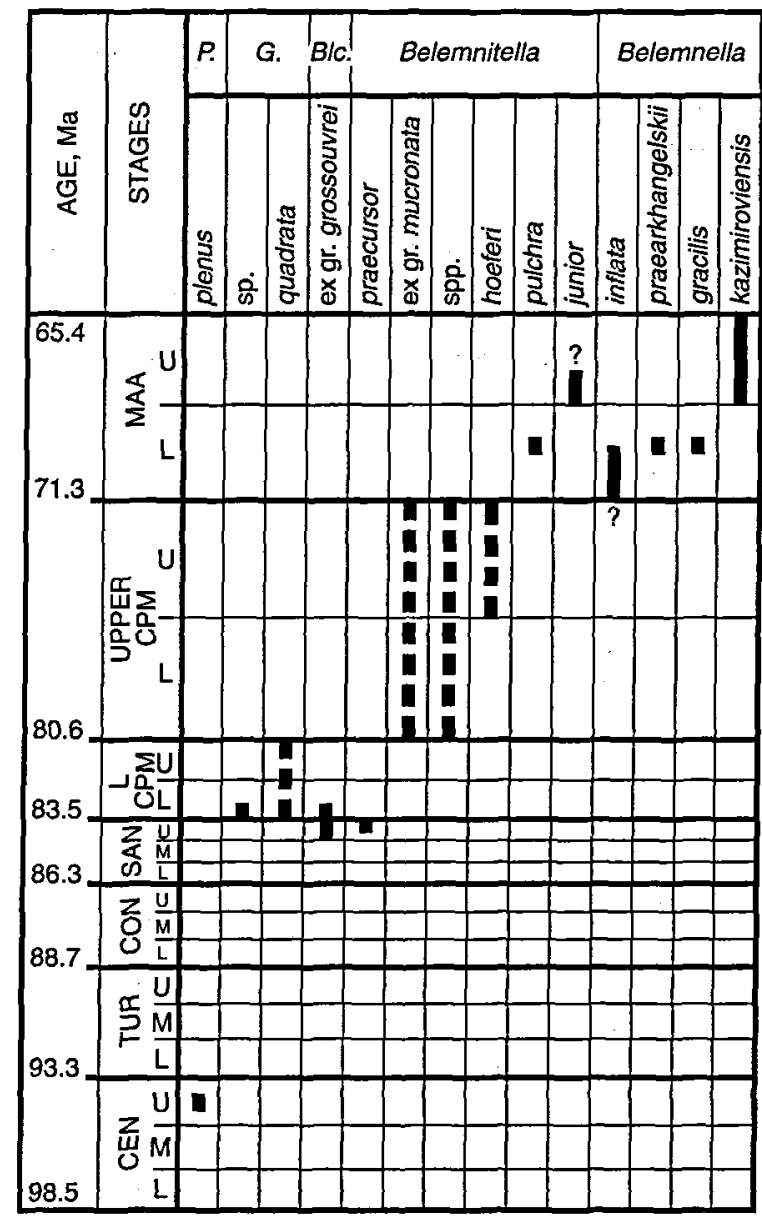

Fig. 4. Stratigraphical range diagram of Late Cretaceous belemnitellids of the Tethyan Realm. $P$. = Praeactinocamax; $G .=$ Gonioteuthis, Blc. = Belemnellocamax. Stage abbreviations after Harland et al. (1989). Ages in Ma after Obradovich (1994).

growth the ratio will change with size. Ratios have been widely used in palaeontological studies, including belemnite studies, but ratios should be used only when the growth is isometric or when specimens of nearly the same size of different species are compared.

Distribution. - The belemnitellids occur in the North European and North American Provinces of the North Temperate Realm, and the northern margin of the Tethyan Realm in Europe.

\section{Genus Actinocamax Miller, 1823}

Type species. - By monotypy Actinocamax verus Miller, 1823, p. 63, Pl. 9: 17.

Emended diagnosis, - Small, stout belemnitellids 
(guard up to $55 \mathrm{~mm}$ long) with isometric growth; generally long cone-shaped alveolar fracture; ventral fissure, ventral furrow, and ventral notch absent; single lateral furrows weakly developed or absent; granulation present in some species.

Discussion. - Naidin (1964b) recognized three subgenera of Actinocamax: A. (Actinocamax), type species $A$. verus; $A$. (Praeactinocamax), type species $A$. plenus; and $A$. (Paractinocamax), type species $A$. grossouvrei.

Christensen (1986) placed A. (Paractinocamax) in synonymy with Belemnellocamax, type species Belemnites mammillatus (see later discussion). The legitimacy of the subgenera Actinocamax and Praeactinocamax was initially questioned by Christensen (1982, 1986, 1991, 1993b, 1994), but they were recognized by Gale \& Christensen (1996) and Christensen \& Schulz (in press), because they differ in several critical characters (see discussion above). Subgenus Praeactinocamax is here elevated to full generic rank due to these differences.

Actinocamax has been the subject of excessive subdivision by Russian palaeontologists. Four species and nine subspecies have been established: $A$. verus (including six subspecies), A. laevigatus (including three subspecies), A. minutus Glazunova, 1972 and $A$. quasiverus Naidin, 1953 . These were discussed by Christensen \& Schulz (in press), who recognized A. v. verus, $A$. verus subfragilis Naidin, $1964 \mathrm{~b}, A$. verus antefragilis Naidin, 1964b, A. laevigatus and A. quasiverus.

Distribution. - Actinocamax occurs mainly in the North European Provinces and is recorded from the Early Turonian to the boundary between the lower and upper part of the Early Campanian (Fig. 1). It occurs extremely rarely in the North American Province. The stratigraphical ranges of the species are shown in Figures 2 and 4 .

A. v. verus is widely distributed and occurs commonly in the North European Province. In northwest Europe it is recorded from the Santonian and early Early Campanian. On Bornholm it enters in the latest Early Santonian, slightly above the appearence of Gonioteuthis westfalica westfalica (Christensen \& Schulz, in press). In offshore chalks it is most common in the late Late Santonian; it has an acme occurrence in the upper part of the early Late Santonian Uintacrinus Zone of southern England. On the Russian Platform it enters in the Coniacian.

$A$. verus antefragilis is recorded from the Early Turonian of the Russian Platform, and A. verus cf. antefragilis was reported recently from the late Early and Middle Coniacian of Bornholm (Christensen \& Schulz, in press). A. verus subfragilis occurs in the late Coniacian of the Russian Platform.

A. laevigatus occurs on the Russian Platform in the so-called 'Pteria'-beds of earliest Early Campanian age; it possibly also occurs in beds of the same age in western Europe (Naidin 1964b). A. quasiverus occurs in the Late Santonian of Crimea.

\section{Genus Praeactinocamax Naidin, 1964b}

Type species. - Belemnites plenus Blainville, 18251827 , p. $376, \mathrm{Pl}$. 11bis: 3, by original designation by Naidin (1964b: 34).

Emended diagnosis. - Medium-sized to large belemnitellids (guard up to $115 \mathrm{~mm}$ long) with allometric growth; adult specimens stouter and more lanceolate in ventral view than juvenile specimens; usually with short cone-shaped alveolar fracture, but some species with a very shallow pseudoalveolus; ventral fissure absent; ventral furrow and ventral notch sometimes present; juvenile guard long and slender (needleshaped).

Discussion. - The genus is generally not granulated, but granulation may occur very rarely in some species and one species, $P$. groenlandicus, is granulated.

The earliest belemnitellid, $P$. primus, enters some way above the base of the Early Cenomanian in the North European Province and is followed upwards by the Late Cenomanian P. plenus. The two species are closely allied and form an evolutionary lineage (Christensen 1974, 1990a). These species are not granulated.

In addition to the two large Cenomanian species, I also include in this genus medium-sized to large species from the Turonian-Early Santonian of the North European and North American Provinces (Figs 2-3). Species from the Central European Subprovince comprise: bohemicus, strehlensis and paderbornensis. They were revised by Christensen (1982), who showed that bohemicus may be granulated, whereas the others are not granulated.

Species from the Central Russian Subprovince include: planus (Makhlin, 1965), coronatus (Makhlin, 1965), intermedius, matesovae, medwedicicus, mujnakensis (Naidin, 1964b) and aralensis (Arkhangelsky, 1912). These species are not granulated.

Species from the North American Province comprise: manitobensis, cobbani, groenlandicus, walkeri, sternbergi, aff. primus and aff. groenlandicus (Fig. 3). P. groenlandicus is granulated (Birkelund 1956) and $P$. cobban $i$ is very rarely granulated (Christensen 1993b). P. sternbergi was established by Jeletzky (1961) on the basis of a single specimen, which differs from $P$. manitobensis only by being granulated. Jeletzky (1961) suggested that $P$. aff. groenlandicus from central West Greenland, which was similarly erected on the basis of a single, granulated specimen, may be either a geographical subspecies or a morphological variety of $P$. sternbergi. Christensen \& Hoch (1983) suggested that $P$. sternbergi should be placed 
Table 1. Univariate analysis of Praeactinocamax plenus from the Plenus Marls of the Betchworth Limeworks, England. $\mathrm{RQ}=$ Riedel-Quotient; $\mathrm{RI}=$ Riedel-Index; $N=$ number of specimens; $\bar{X}=$ mean value; $S D=$ standard deviation; $\mathrm{CV}=$ coefficient of variation; $\mathrm{OR}=$ observed range.

\begin{tabular}{lrrrrr}
\hline Character & $N$ & $\bar{X}$ & \multicolumn{1}{c}{ SD } & \multicolumn{1}{l}{ CV } & \multicolumn{1}{l}{ OR } \\
\hline $\mathrm{RQ}$ & 10 & 39.6 & 15.8 & 39.8 & $23.3-87.6$ \\
$\mathrm{RI}$ & 10 & 2.8 & 0.9 & 31.6 & $1.3-4.3$ \\
\hline
\end{tabular}

in synonymy with $P$. manitobensis, because granulation may occur very rarely in this species. The species from the North American Province were discussed by Christensen (1993b).

Birkelund (1956) referred one specimen of unknown age from central West Greenland to $P$. aff. primus. This determination is open to discussion, because the specimen is enclosed in matrix and only the side is exposed. It is so poorly preserved that it cannot be orientated with certainty. Moreover, $P$. primus occurs in the Lower and Middle Cenomanian in the North European Province, but Cenomanian belemnitellids are not recorded elsewhere in the North American Province.

P. primus usually has a short cone-shaped alveolar fracture. Specimens with a flat anterior end are rare and specimens with a shallow pseudoalveolus are extremely rare (Christensen 1990a). A specimen from Bórnholm, MGUH 7834, figured by Birkelund (1957, Pl: 1: 2) and Christensen (1990a, Fig. 3C), häs a Riedel-Quotient of c. 46 and a Riedel-Index of $c .2$. Christensen (1974) analyzed a large sample of $P$. plenus from the Plenus Marls of the Betchworth Limeworks in southern England. He showed that most specimens have a low cone-shaped alveolar fracture, and that about $7 \%$ of the specimens have a shallow pseudoalveolus, with all intermediate forms. I have subsequently analyzed the variation of the RiedelQuotient and Riedel-Index of the specimens with a shallow pseudoalveolus (Table 1).

$P$. manitobensis include morphological variants with either a low cone-shaped alveolar fracture, a flat anterior end or a shallow pseudoalveolus (Jeletzky 1950, 1961). According to Jeletzky (1961, Pl. 1: 2), specimen no. 7936-2 has a Riedel-Quotient between 17.5 and 19.4.

Five species from the Russian Platform have a shallow pseudoalveolus or a flat anterior end with a central pit. The Riedel-Quotient is 11 to 13 in the Late Coniacian $P$. aralensis and Late Turonian $P$. matesovae, 16 to 18 in the Late Turonian P. coronatus, 13 to 25 in the Late Coniacian P. mujnakensis and about 15 in the Late Turonian $P$. medwedicicus. In contrast to Naidin (1964b) and Makhlin (1965), who placed these species in Gonioteuthis (Goniocamax), they are here assigned to Praeactinocamax, because the pseudoalveolus is relatively shallow. However, these spe- cies may be transitional forms between the genera Praeactinocamax and Goniocamax.

Distribution. - Praeactinocamax occurs in the North American and North European Provinces, in addition to the northern part of the Tethyan Realm in Europe. It appears in the Early, but not earliest, Cenomanian and continues into Early Santonian. The stratigraphical ranges of the species are shown in Figures 2-4.

\section{Genus Belemnocamax Crick, 1910}

Type species. - By monotypy Belemnocamax boweri Crick, 1910, p. 364, Pl. 28: 1-2.

Diagnosis. - Very small belemnitellid (guard up to 25 $\mathrm{mm}$ long), conical in lateral and ventral views, and with acute apex; anterior end with pseudoalveolus; Riedel-Quotient from about 4 to 7; walls of pseudoalveolus sometimes with conellae; guard with long, broad, and deep ventral groove extending from the anterior end; length of groove $1 / 3$ to $1 / 4$ of length of guard; dorso-lateral longitudinal depressions distinct, delimiting the dorsal field; dorso-lateral depressions from anterior end and almost to apex; single lateral furrows present; guard with longitudinal striae, but otherwise smooth.

Discussion. - Christensen (1993c) described B. boweri on the basis of a small sample, consisting of 18 specimens, from the limestone pit at Wunstorf, west of Hannover, Lower Saxony Basin. In addition, three specimens from Dörenthe, Münster Basin, and eight specimens from eastern England, including the holotype, were also studied.

$B$. boweri differs from all other belemnitellid genera by the size and shape of the guard, and by having a long, broad, and deep ventral groove.

The ancestry of $B$. boweri is unknown. J. A. Jeletzky (unpublished MS 1972) suggested that it probably represents an early independent offshoot of a still unknown pre-Cenomanian form between Neohibolites and Actinocamax, and that this aberrant genus died out without issue.

Distribution. - B. boweri is very rare and has a very restricted distribution. It occurs in the early Middle Cenomanian of the Lower Saxony and Münsterland Basins in northwest Germany, the Cleveland Basin in eastern England and at Hunstanton, Norfolk.

\section{Genus Gonioteuthis Bayle, 1878}

Type species. -Belemnites quadratus Blainville, 1827 , p. 62, Pl. 1: 9, by original designation of Bayle (1878, caption to Pl. 22: 6-8). 


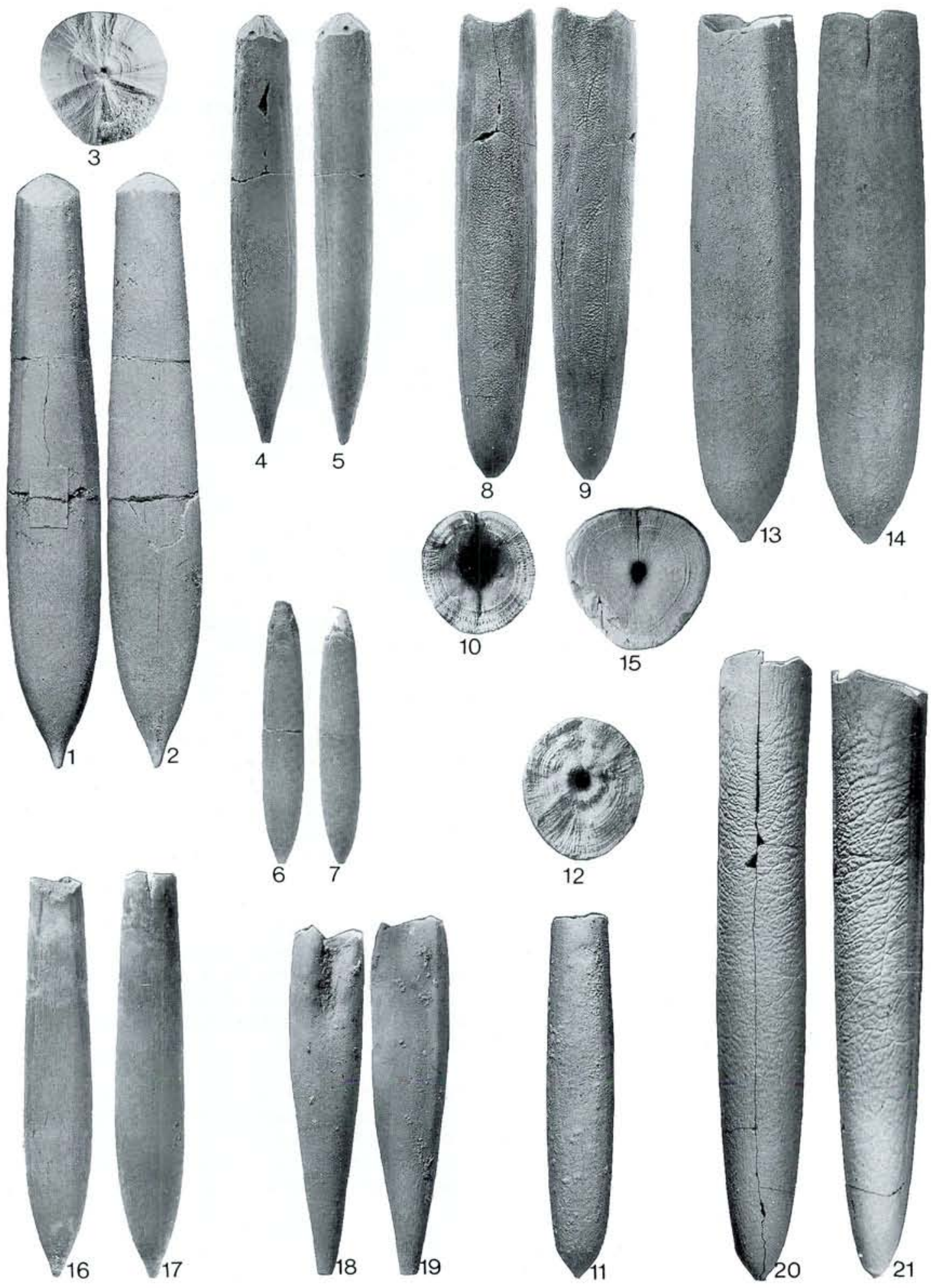

Plate I 


\section{Plate 1}

Figs 1-3.Praeactinocamax plenus (Blainville, 1825-1827), Sedgwick Museum, B76709, Betchworth Limeworks, Surrey, England, Plenus Marls, middle Late Cenomanian; 1, dorsal view; 2 , ventral view; 3 , view of the anterior end showing concentric growth layers and radial ridges, $\times 2$. A large species of Praeactinocamax. Figured by Christensen (1974, Pl. 4: 4).

Figs 4-5. Praeactinocamax cobbani Christensen, 1993 holotype, U.S. Geological Survey, USGS 21411/16, Kevin Member, Marias River Shale Formation, Montana, Scaphites preventricosa/Inoceramus deformis Zone, early Middle Coniacian; 4, dorsal view; 5, lateral view. A mediumsized species of Praeactinocamax. Figured by Christensen (1993b, Figs 5.17-20).

Figs 6-7. Actinocamax verus verus Miller, 1823, Geological Museum, Copenhagen, MGUH 23718, Bavnodde Greensand Formation, Bornholm, Denmark, west of Bavnodde, between beds 3 and 5, Early Santonian; 6, dorsal view; 7, lateral view. Figured by Christensen \& Schulz (in press, P1. 1: 2).

Figs 8-10. Gonioteuthis quadrata quadrata (Blainville, 1827), Geological Museum, Copenhagen, MGUH 17529, Vaals Formation, CPL quarry, Hallembaye, Belgium, lower part of Inoceramus lingua/Gonioteuthis quadrata Zone, early, but not earliest, Early Campanian; 8, dorsal view; 9, lateral view; 10 , view of the anterior end, $\times 1.5$. A species with a deep pseudoalveolus and well-developed granulation. Figured by Christensen \& Schmid (1987, Pl. 3: 811).

Figs 11-12. Gonioteuthis westfalica (Schlüter, 1874), Geological Institute, Lund, Sweden, LO 4859, Ringeleslätt, Scania, Sweden, early Santonian; 11 , dorsal view; 12 , view of the anterior end, $\times 2$. A specimen of $G$. westfalica which has a flat anterior end with a central pit. Figured by Christensen (1975a, Pl. 2: 4).

Figs 13-15. Belemnellocamax mammillatus (Nilsson, 1826), Geological Museum, Copenhagen, MMH 13078, Ignaberga new quarry, Scania, Sweden, latest Early Campanian; 13 , dorsal view; 14 , ventral view; 15 , view of the anterior end, $\times 1.5$. Figured by Christensen (1975a, Pl. 3: 6).

Figs 16-17. Goniocamax lundgreni (Stolley, 1897), Geological Museum, Copenhagen, Denmark, MMH 1690, Arnager Limestone Formation, west of Arnager, Bornholm, Early Coniacian; 16, dorsal view; 17, ventral view. Figured by Christensen \& Schulz (in press, Pl. 2: 1).

Figs 18-19. Belemnocamax boweri Crick, 1910, Geological Museum, Copenhagen MGUH 22068 (cast), Wunstorf, Lower Saxony, Germany, early Middle Cenomanian, Acanthoceras rhotomagense Zone, Turrilites costatus Subzone; 18 , ventral view, $\times 3 ; 19$, lateral view, $\times 3$. Figured by Christensen (1993c, Fig. 3F).

Figs 20-21. Belemnitella mucronata (Schlotheim, 1813), neotype, Niedersächsiches Landesamt für Bodenforschung, Hannover, Germany, kca 5/2, Germania IV pit at Misburg near Hannover, middle part of the basiplana/spiniger Zone, early, but not earliest, Late Campanian; 20, ventral view; 21 , lateral view. A large species of Belemnitella with a stout guard. Figured by Christensen et al. (1975, P1. 1: 1).

All specimens are coated with ammonium chloride, and are natural size unless otherwise stated.
Diagnosis. - Medium-sized belemnitellids (up to 85 $\mathrm{mm}$ long), with a short cone-shaped alveolar fracture or pseudoalveolus of varying depth (Riedel-Quotient from 3 to 20); guard usually only slightly flattened or not flattened at all ventrally; generally subcylindrical or cylindrical in ventral view and cylindrical in lateral view; juvenile guard short and stout; surface markings, including dorso-lateral longitudinal depressions and double furrows, vascular imprints, striae, and granules, well developed; Schatzky distance small, usually 0.5 to $4.5 \mathrm{~mm}$; bottom of ventral fissure commonly sine-shaped forming a large angle with the wall of the pseudoalveolus; vascular imprints branch off dorso-lateral double furrows posteriorly at an angle less than 30 degrees; relationship between length of guard and dorso-ventral diameter at the alveolar end generally allometric.

Discussion. - Naidin (1964b) recognized two subgenera of Gonioteuthis: $G$. (Gonioteuthis), type species Belemnites quadratus and $G$. (Goniocamax), type species Actinocamax lundgreni. Christensen \& Schulz (in press) elevated subgenus Goniocamax to full generic rank, following an earlier suggestion by Ernst \& Schulz (1974) (see discussion below).

The Middle Coniacian to Early. Campanian evolutionary lineage of Gonioteuthis includes, in ascending order, G. praewestfalica, G. westfalica, $G$. westfalicagranulata (Stolley, 1897), G. granulata (Blainville, 1827), G. granulataquadrata (Stolley, 1897), G. q. quadrata and $G$. quadrata gracilis (Stolley, 1892) (Fig. 2). It has been studied in great detail by German authors, including Stolley (1892, $1897,1916,1930)$, Ernst (1964, 1966, 1968), Ernst \& Schulz (1974) and Ulbrich (1971), in addition to Christensen (1975a, 1975b, 1986, 1991, 1994), Christensen \& Schmid (1987), Christensen \& Schulz (in press), Jarvis (1980) and Jagt, Kennedy, Burnett, Christensen \& Dhondt (1995). In addition to the members of this evolutionary lineage the following species and subspecies are placed in Gonioteuthis: the Early Santonian G. ernsti Christensen \& Schulz (in press), which occurs on Bornholm and in the Münster Basin and G. quadrata scaniensis Christensen, 1975a from the latest Early Campanian of Scania (Christensen 1975a, 1986) (Fig. 2). According to Christensen (1975a, 1986) the latter taxon is a geographical subspecies, which is closely allied to G. quadrata gracilis.

The Gonioteuthis lineage survived for around $7 \mathrm{Ma}$ and has been considered as an example of phyletic gradualism, viz. gradual transformation of a suite of characters through time. The general trends in evolution are: (1) gradual calcification of the anterior end of the guard, (2) increasing size and stoutness of the guard and (3) gradual development of granulation (Ernst 1964, Ernst \& Schulz 1974).

In the oldest member of the lineage, the late Middle Coniacian-early Early Santonian G. praewestfalica, 

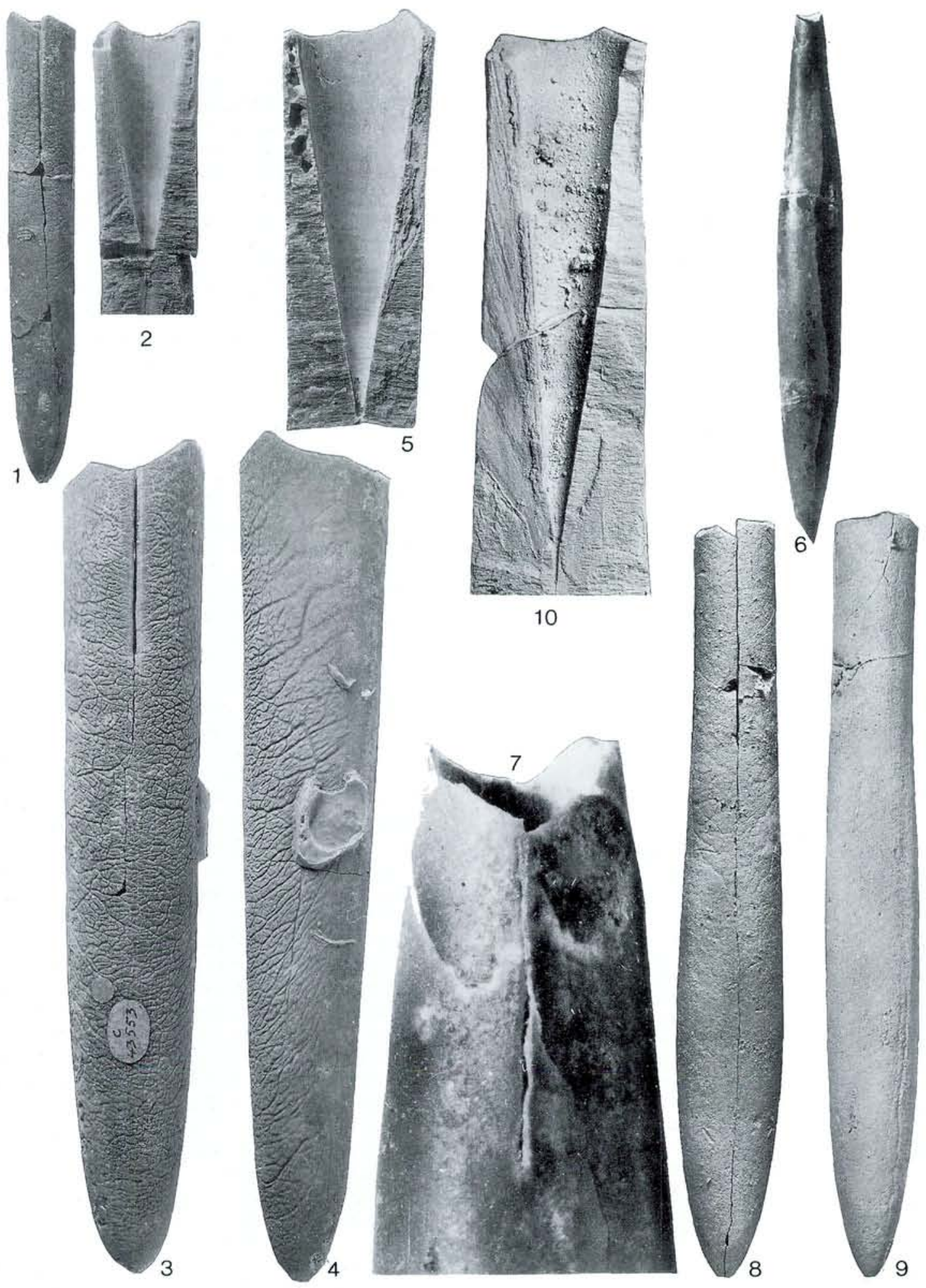

Plate 2 
less than $10 \%$ of the specimens are granulated, whereas in the succeeding species, the late Early-early. Middle Santonian $G$. westfalica, about the half of the specimens are granulated (Christensen \& Schulz, in press). Granulation becomes a very promiment character in younger species. With respect to the depth of the pseudoalveolus, Christensen \& Schulz (in press) showed that $G$. praewestfalica has a deeper pseudoalveolus than $G$. westfalica from the early Early Santonian, and the depth of the pseudoalveolus is virtually identical in G. praewestfalica and G. westfalica from the late Early Santonian. Thus, the depth of the pseudoalveolus first decreases from the late Middle Coniacian to the early Early Santonian and this trend is reversed in the late Early Santonian.

Ernst (1964) and Christensen (1991) noted that coeval populations of $G$. q. quadrata from the middle Early Campanian chalk of Lägerdorf and marl of Misburg/Höver in northwest Germany differ with respect to the depth of the pseudoalveolus. The specimens from Misburg/Höver have a slightly deeper pseudoalveolus. The specimens from Lägerdorf are thus phylogenetically retrograde compared to coeval specimens from Misburg/Höver. G. quadrata scaniensis from Scania is also phylogenetically retrograde in comparison with the coeval G. quadrata gracilis from northwest Germany. The mean Riedel-Quotient of sca-

Plate 2

Figs 1-2. Belemnitella najdini Kongie1, 1962, British Geological Survey, Nottingham, BGS CJW 5478, Caistor, Norfolk, Beeston Chalk, between Flint 9-10, late Late Campanian; 1 , ventral view; 2 , view of the split anterior end, $\times 1.5$. A small, slender species of Belemnitella. Schatzky Distance small, $7.7 \mathrm{~mm}$; fissure angle large, 120.5 degrees; Birkelund Index, 4.7. Figured by Christensen (1995, Pl. 4: 1-4).

Figs 3-5. Belemnitella minor Jeletzky, 1951 form II Christensen, 1995, holotype, Natural History Museum, London, BMNH C43553, Whitlingham, Norfolk, Paramoudra, Chalk, late, but not latest, Late Campanian; 3, ventral view; 4 , lateral view; 5 , view of the split anterior end. A stout and very large species of Belemnitella with well-developed vascular markings. Schatzky. Distance large, $12.0 \mathrm{~mm}$; fissure angle small, 15.5 degrees; Birkelund Index, 3.4. Figured by Christensen (1995, Pl. 7: 3-6; Fig. 20D).

Figs 6-7. Fusiteuthis polonica Kongiel, 1962, holotype, Bochotnica, Poland, latest Maastrichtian; 6, ventral view; 7 , ventral view of the anterior part of the guard, approximately $\times 6$. Figured by Kongiel (1962, P1. 1: 1-3).

Figs 8-10. Belemnella lanceolata (Schlotheim, 1813), Geological Museum, Copenhagen, MMH 13115, Balsvik, Scania, Sweden, earliest Early Maastrichtian; 8, ventral view; 9, lateral view; 10; view of the split anterior end, $\times 2$. Figured by Christensen (1975a, Pl. 12: 4).

All specimens are coated with ammonium chloride, except Figs 6-7, and are natural size unless otherwise stated. niensis is 5.1 (Christensen 1975a), while it is \pm 4.5 in gracilis (Ernst 1964).

Mitchell $(1994,1995)$ showed that populations of Gonioteuthis from the Late Santonian Marsupites testudinarius and Uintacrinus socialis Zones of Yorkshire are phylogenetically retrograde in comparison with coeval populations from northwest Germany. He also demonstrated that populations of Gonioteuthis from the early Early Campanian of Yorkshire and northwest Germany have reached the same evolutionary development.

It can thus be concluded that the evolution of Gonioteuthis lineage with respect to the depth of the pseudoalveolus is not as straigthforward as supposed earlier. The depth of the pseudoalveolus first decreases and then increases in its earliest members, and the evolutionary development of populations of the lineage may be delayed in some areas.

Distribution. - Gonioteuthis had its evolutionary centre in northwest Europe and is recorded almost exclusively from the Central European Subprovince. It occurs very rarely in the northern part of the European Tethyan Realm. The genus existed from the late Middle Coniacian to the boundary between the Early and Late Campanian (Fig. 1). The stratigraphical ranges of the species are shown in Figure 2.

Genus Belemnellocamax Naidin, 1964b

[= Actinocamax (Paractinocamax) Naidin, 1964b, p. 62]

Type species, - Belemnites mammillatus Nilsson, 1826 , p. 340, by original designation of Naidin (1964b: 153).

Diagnosis. - Large belemnitellids (up to $130 \mathrm{~mm}$ long), with a shallow to relatively deep pseudoalveolus; guard markedly flattened ventrally, lanceolate or subcylindrical in ventral view, and subcylindrical to slightly lanceolate in lateral view; dorso-lateral longitudinal depressions and double furrows usually welldefined, vascular imprints faint or absent; Schatzky distance small, $0-2 \mathrm{~mm}$; vascular imprints branch off dorso-lateral double furrows posteriorly at an angle of about 60 degrees; relationship between length of guard and dorso-ventral diameter at protoconch strongly allometric; juvenile guard very long and slender (needle-shaped).

Discussion. - The evolutionary lineage of Belemnellocamax includes, in ascending order, $B$. ex gr. grossouvrei, B. mammillatus and B. balsvikensis (see Christensen 1986). The general trends in evolution are the gradual calcification of the adoral end and the shape changes in which the guard becomes more slender and less lanceolate. The genus is usually not granulated, 
but a few granulated specimens of $B$. ex gr. grossouvrei and $B$. mammillatus have been recorded (Christensen 1986).

Naidin (1964b) placed species of the grossouvrei group in his new subgenus Actinocamax (Paractinocamax), type species $A$. grossouvrei, and mammillatus in his new genus Belemnellocamax. He distinguished A. (Paractinocamax) from Belemnellocamax on the basis of the size of the juvenile guard and claimed that $A$. (Paractinocamax) has a short juvenile guard, while Belemnellocamax has a long and slender juvenile guard. Christensen (1986) noted, however, that specimens of the grossouvrei group from west Europe have a very elongated juvenile guard. He therefore placed the grossouvrei group in Belemnellocamax, and A. (Paractinocamax) was considered a junior synonym of Belemnellocamax. Christensen (1991) figured two juvenile specimens of $B$. ex gr. grossouvrei from southern England, both of which are very elongated.

The grossouvrei group is rare; about 60 specimens are known from west Europe, and about 60-70 specimens are recorded from the Russian Platform. The specimens from west Europe have been assigned to eight species and varieties: grossouvrei, toucasi (Janet, 1891), alfridi (Janet, 1891), depressus (Andreae, 1895), depressus var. fusiformis (Andreae, 1895), mammillatus var. germanica (Stolley, 1930), mammillatus var. ornatus (Moberg, 1885) and blackmorei (Crick, 1907).

Naidin (1964b) distinguished five subspecies of $B$. grossouvrei: depressus, toucasi and alfridi from west Europe, and two new subspecies, pseudotoucasi and pseudoalfridi, from the Russian Platform. In addition, Nikitin (1958) established $B$. toucasi var. seimensis and Glazunova (1972) recorded $B$. cf. toucasi and $B$. alfridi from the Russian Platform.

To sum up, eleven taxa have been established within the grossouvrei group on the basis of relatively little material. Thus, the group has been the subject of excessive subdivision by previous authors. The group is currently being revised by W. K. Christensen and M.G. Schulz, Kiel on the basis of material from west Europe.

Distribution. - The genus appears probably at the base of the Santonian and continues into the early Late Campanian (Figs 1-2). The Santonian-Early Campanian $B$. ex gr. grossouvrei is widely distributed but rare in the North European Province; it occurs from Scania in southern Sweden in the north to the Corbières in the French Pyrénées in the south. The latest Early Campanian $B$. mammillatus is extremely common in Scania, but rare outside this area; a little over 100 specimens are recorded from northern Germany, Poland and the eastern part of the Russian Platform (Christensen 1975a). The early Late Campanian $B$. balsvikensis is also extremely common in Scania, but outside this area it is unknown except for two speci- mens from northwest Germany. Thus, the geographical distribution of the genus was gradually reduced during its stratigraphical range.

\section{Genus Goniocamax Naidin, 1964b}

Type species. -Actinocamax lundgreni Stolley, 1897, p. 285 , Pl. 3: 16-20, non 15 , by original designation of Naidin (1964b: 104).

Emended diagnosis. - Small to medium-sized (up to $80 \mathrm{~mm}$ long) non-granulated belemnitellids, with a shallow to relatively deep pseudoalveolus; guard markedly flattened ventrally, lanceolate in ventral view and subcylindrical in lateral view; juvenile guard short and stout; guard with dorso-lateral longitudinal depressions and double furrows, vascular imprints, and longitudinal striae; longitudinal striae usually more distinct than vascular markings; Schatzky distance small, 2 to $4 \mathrm{~mm}$; bottom of ventral fissure commonly straight or slightly curved forming a medium-sized angle, about 30 to 50 degrees, with wall of pseudoalveolus; vascular imprints branch off dorso-lateral double furrows posteriorly at an angle less than 30 degrees; allometric relationship of length of guard and dorso-ventral diameter at protoconch; adults stouter than juveniles.

Discussion. - Christensen \& Schulz (in press) raised the subgenus Gonioteuthis (Goniocamax) to full generic rank and included the type species and its close allies in Goniocamax, that is G. birkelundae Christensen \& Schulz (in press), G. striatus Christensen \& Schulz (in press), G. esseniensis (Christensen, 1982) and G. mirabilis (Arkhangelsky, 1912).

Goniocamax is closely similar to Gonioteuthis, but differs from that genus by being non-granulated, flattened ventrally, lanceolate in ventral view, and the bottom of the ventral fissure is usually straight or slightly curved forming a medium-sized angle with the wall of the pseudoalveolus.

Distribution. - Goniocamax occurs mainly in the Central Russian Subprovince and Balto-Scandia. It occurs very rarely in the Central European Subprovince. It appears at the base of the Coniacian and continues into the Early Santonian (Christensen \& Schulz, in press) (Fig. 1). The stratigraphical ranges of most of the species are shown in Figure 2.

Genus Belemnitella d'Orbigny, 1840

[ICZN 1985, Opinion 1328; name no. 2269]

Type species. - Belemnites mucronatus Schlotheim, 1813 , p. 111 , by subsequent designation by Herrmannsen (1846: 105); ICZN Opinion 1328 (1985); name no. 2979. 


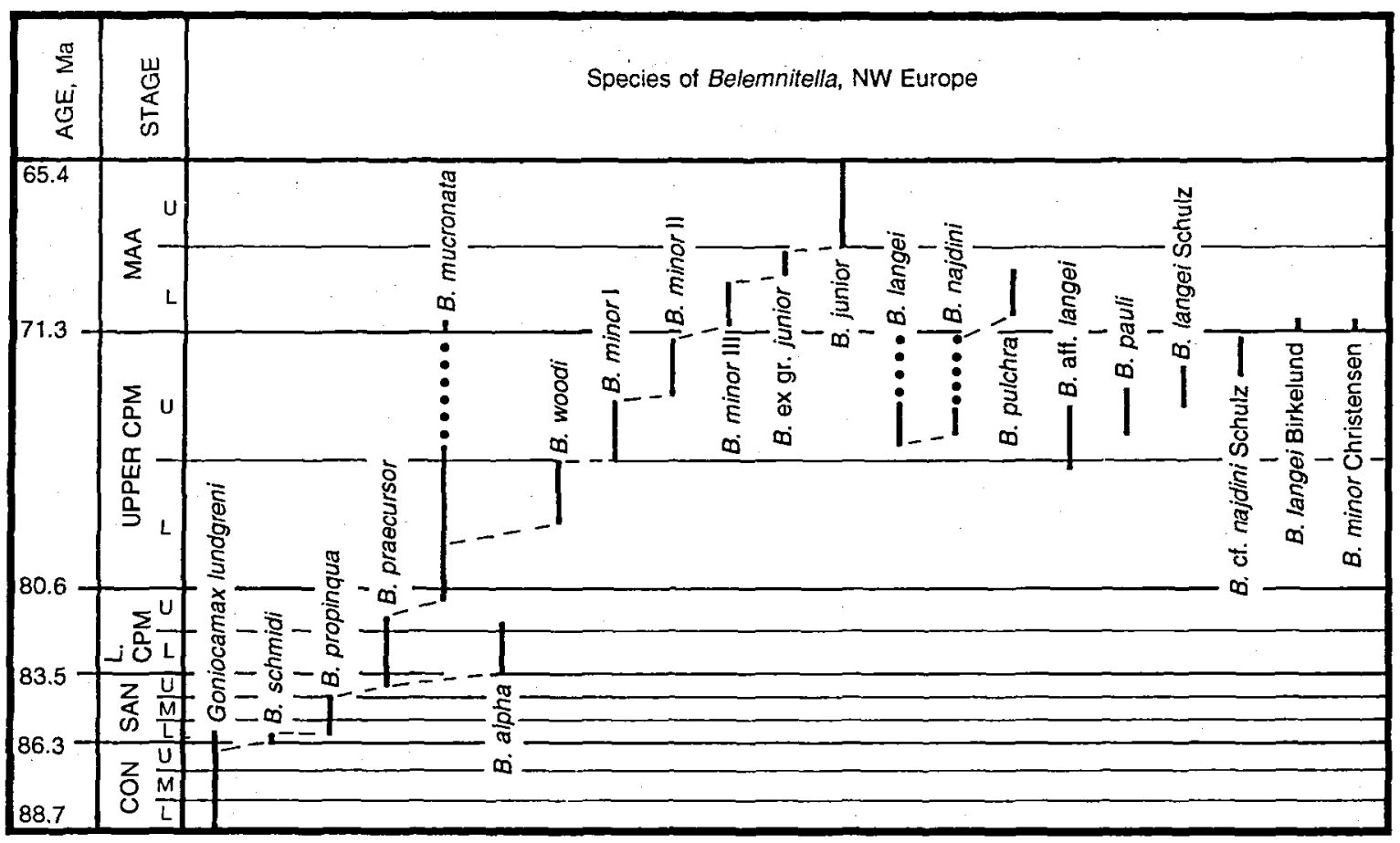

Fig. 5. Stratigraphical range and inferred phylogeny of Santonian-Maastrichtian species of Belemnitella. Modified from Christensen (1995). Stage abbreviations after Harland et al. (1989). Ages in Ma after Obradovich (1994).

Diagnosis. - Small to large belemnitellids (length from apex to protoconch up to $80 \mathrm{~mm}$ ) with a deep alveolus; anterior end of guard completely calcified and prolonged ventrally along ventral fissure in a tonguelike extension; well developed dorso-lateral longitudinal depressions and straight double furrows, in addition to single lateral furrows; longitudinal striae may be present; vascular imprints branch off double furrows posteriorly at an angle less than 30 degrees; juvenile guard short and stout; alveolar angle 17 to 24 degrees, Schatzky distance long, copmmonly larger than $4 \mathrm{~mm}$; relationship of length from apex to protoconch and dorso-ventral diameter at protoconch generally isometric.

Discussion. - Christensen (1995) introduced a classification of size ranges of species of Belemnitella based on the length from the apex to the protoconch. This is as follows: (1) guard small; length from apex to protoconch less than $55 \mathrm{~mm}$; (2) guard large; length from apex to protoconch between 55 and $65 \mathrm{~mm}$; (3) guard very large; length from apex to protoconch larger than $65 \mathrm{~mm}$. He also introduced a classification of the relative length of species of Belemnitella based on the Birkelund Index. This is as follows: (1) guard stout; mean value of Birkelund Index less than 4 ; (2) guard slender; mean value of Birkelund Index 4 to 5; (3) guard very slender; mean value of Birkelund Index larger than 5. It should be stressed that it is ac- ceptable to calculate the mean value of the Birkelund Index in species of Belemnitella, because the relationship of the length from the apex to the protoconch versus the dorso-ventral diameter is generally isometric (Christensen 1995).

More than two dozen species, subspecies, and varieties of Belemnitella from the Late Campanian and Early Maastrichtian have been established. Many of these are poorly understood, because they were commonly erected on the basis of relatively little material, and the variation of the critical characters was rarely studied (Christensen 1988, 1993a).

Christensen \& Schulz (in press) established Belemnitella schmidi, which appears at the base of the Santonian. They considered this species as the earliest member of Belemnitella. It is a transitional form possessing characters in common with the genera Goniocamax and Belemnitella. It probably evolved from Goniocamax lundgreni by allopatric speciation. B. propinqua (Moberg, 1885) enters some way above the base of the Santonian and is probably the lineal descendent of B. schmidi (Christensen \& Schulz, in press). $B$. propinqua was considered previously to be the earliest member of Belemnitella by Jeletzky (1949b, 1955), Naidin (1964a, 1964b, 1974) and Christensen $(1971,1973,1991)$, although some authors, including Birkelund (1957) and Glazunova (1972), placed it in Actinocamax.

Christensen (1995) analyzed the evolutionary trends 
of Belemnitella from the Early Santonian to the Late Maastrichtian on the basis of biometric analyses of 43 samples, representing 20 species and subspecies. He tentatively recognized two lineages of Belemnitella (Fig. 5):

(1) A Santonian-Maastrichtian lineage, which is derived from Goniocamax lundgreni. It includes $B$. schmidi, $B$. propinqua, $B$, praecursor, $B$. woodi Christensen, 1995, B. minor I Jeletzky, 1951, $B$. minor II Christensen, 1995, B. minor III Christensen, 1995, B. ex gr. junior sensu Keutgen \& van der Tuuk, 1990 and $B$. junior. These species are large to very large and stout to slender. In addition, the fissure angle is small to medium-sized, the bottom of the ventral fissure is generally straight and the Schatzky distance is medium-sized to large.

(2) A late Late Campanian-Early Maastrichtian lineage, which comprises the late Late Campanian $B$. langei Jeletzky, 1948 and B. najdini Kongiel, 1962, in addition to the Early Maastrichtian B. pulchra Schulz, 1982. These species are small and slender to very slender. Moreover, the fissure angle is large to very large, the bottom of the ventral fissure is irregular and the Schatzky distance is small. The origin of this lineage is unknown.

In addition to the species of the two lineages, other species are recorded from the Campanian and basal Maastrichtian. The early Early Campanian $B$. alpha Naidin, 1964a is probably an off-shoot derived from B. praecursor (see Christensen 1995). Species of unknown origin or poorly known species include the late Late Campanian B. aff. langei of Christensen (1986, 1993a), B. langei sensu Schulz (1978), B. cf. najdini of Schulz (1978) and B. pauli Christensen, 1995, in addition to the basal Maastrichtian $B$. minor sensu Christensen (1975a) and B. langei sensu Birkelund (1957). The latter was placed in synonymy with $B$. minor III with a query by Christensen (1995), who also discussed the species mentioned above.

The little known late Late Campanian Belemnitella hoeferi (Schloenbach, 1867) from the Northern Calcareous Alps of Austria is a valid species, which belongs to the B. mucronata group of Christensen (1995). Christensen (submitted) redescribed this species, including biometric analysis, on the basis of material from the Gschliefgraben area in Austria. It can be distinguished from most species of the $B$. mucronata group on the basis of the slender guard (mean Birkelund Index about 4.5). Belemnitella sp. from the 'Craie marneuse' of Chartreuse in the Sub-Alpine Chain, Savoie, southeast France (Combémorel 1996) is closely similar to $B$. hoeferi with respect to size, shape and slenderness of the guard, in addition to surface markings. Thus, the two taxa may be conspecific, but a specific determination of the specimens from Chartreuse is not possible, because the internal characters are unknown.
Distribution. - Belemnitella as interpreted here appears at the base of the Santonian and continues to the top of the Maastrichtian (Fig. 1). It is recorded from the North European and North American Provinces, in addition to the northern part of the Tethyan Realm. The stratigraphical ranges of the species are shown in Figures 2-5.

Genus Belemmnella Nowak, 1913

[ICZN 1985, Opinion 1328; name no. 2270]

Type species. - Belemmnites lanceolatus Schlotheim, 1813 , p. 111 , by subsequent designation by von Bülow-Trümmer (1920: 195); ICZN Opinion 1328 (1985); name no. 2980.

Diagnosis. - Large belemnitellids (length from apex to protoconch up to $110 \mathrm{~mm}$ ) with a deep alveolus; anterior part of guard complete calcified and prolonged ventrally around ventral fissure in a tongue-like extension; guard markedly flattened ventrally; well-developed dorso-lateral longitudinal depressions and double furrows, which undulate posteriorly, in addition to single lateral furrows; vascular imprints weakly developed or not present in early forms, younger forms with distinct vascular imprints; vascular imprints branch off dorso-lateral double furrows posteriorly at an angle exceeding 30 degrees; juvenile guard long and slender (needle-shaped); alveolar angle small, 10 to 21 degrees; Schatzky distance short, 0 to $4.5 \mathrm{~mm}$, commonly less than $4 \mathrm{~mm}$; relationship of length from apex to protoconch and dorso-lateral diameter at protoconch allometric; adult specimens stouter than juvenile specimens.

Discussion. - Three subgenera have been established, the nominotypical subgenus and $B$. (Pachybelemnella) Schulz, 1979, which are Early Maastrichtian (Schulz 1979), in addition to the Late Maastrichtian B. (Neobelemnella) Naidin, 1975. These subgenera include only large species in contrast to the genus Belemnitella (see above).

Schulz (1979) studied the Early Maastrichtian subgenera in great detail and stressed the importance of the shape of the guard in ventral view compared with the length from the apex to the protoconch. Since growth is allometric in Belemnella he introduced the derived variable 'standardized length from the apex to the protoconch' in order to compare specimens of different size. The calculation of this variable is rather laborious. The shape of the guard in ventral view is defined by an index, which includes three different measurements of the lateral diameter.

Schulz distinguished two Early Maastrichtian subgenera of Belemnella: the slender B. (Belemnella) and the stout $B$. (Pachybelemnella). 
Subgenus Belemnella (Belemnella) Nowak, 1913

Diagnosis. - Belemnella with a slender guard; species with a lanceolate guard very slender; species with cylindrical to cone-shaped guard slender.

Discussion. - Schulz (1979) recognized two, possibly three, evolutionary lineages within Belemnella (Belemnella). A lineage including lanceolata (oldest), gracilis (Arkhangelsky, 1912) and fastigata Schulz, 1979 (youngest) (Fig. 2). The general trends of this lineage are: (1) the decreasing length from the apex to the protoconch, (2) the shape of the guard in ventral view changes from lanceolate to cylindrical, (3) the increasing Schatzky Distance and (4) the increasing alveolar angle. Another lineage includes lanceolata and longissima Schulz, 1979 (Fig. 2). The latter taxon is characterized by its very large length from the apex to the protoconch and its very lanceolate shape in ventral view.

Schulz (1979) placed B. praearkhangelskii Naidin, 1964a in subgenus Belemnella with a query (Fig. 2). This species occurs only at a very restricted horizon at Hemmoor and Kronsmoor, that is in the middle part of the sumensis Zone, 35-38 $\mathrm{m}$ above the base of the Maastrichtian. He also recorded four unhorizoned specimens of this taxon from Møns Klint, Denmark, and Rügen, Germany, which may have come from the same zone. Keutgen in Jagt et al. (1995) has subsequently reported the species from the middle part of the sumensis Zone of northeast Belgium. Schulz (1979) suggested that $B$. praearkhangelskii probably belongs to another evolutionary lineage.

$B$. (B.) lanceolata has been widely used as a zonal index fossil of the early Early Maastrichtian (see discussion by Christensen 1996). Schulz' (1979) concept of this species is more restricted, however, than earlier authors, including Jeletzky (1951), Naidin (1952) and Birkelund (1957). He recorded $B$. (B.) lanceolata only from the earliest Early Maastrichtian.

Distribution. - This subgenus is distributed in the Early Maastrichtian (Fig. 1) and occurs in the North European Province and northern part of the Tethyan Realm. The stratigraphical ranges of the species are shown in Figure 2.

\section{Subgenus Belemnella (Pachybelemnella) Schulz, 1979}

Type species. $-B$. (P.) obtusa Schulz, 1979, p. 106, Pl. 9: 1-8, Pl. 12: 9, by original designation.

Diagnosis. - Belemnella with a stout guard; species with a very lanceolate guard slender; species with a lanceolate or cylindrical guard stout.

Discussion. - Schulz (1979) distinguished two lineages within this subgenus. A lineage including inflata
(Arkhangelsky, 1912) (oldest), pseudobtusa Schulz, 1979, obtusa, sumensis Jeletzky, 1949 a and cimbrica Birkelund, 1957 (youngest) (Fig. 2), which is derived from $B$. (B.) lanceolata. The general trends in this lineage are (1) the decreasing length from the apex to the protoconch, (2) the shape of the guard in ventral view changes from lanceolate to cylindrical, (3) the increasing Schatzky Distance and (4) the increasing alveolar angle. Another lineage includes inflata and desnensis (Jeletzky, 1941) (Fig. 2). The latter species has a guard which is strongly lanceolate in ventral view.

Distribution. - Belemnella (Pachybelemnella) is distributed in the Early Maastrichtian (Fig. 1) and occurs in the North European Province and northern part of the Tethyan Realm. The stratigraphical ranges of the species are shown in Figure 2.

Subgenus Belemnella (Neobelemnella) Naidin, 1975

Type species. - By monotypy Belemnitella kazimiroviensis Skołosdrówna, 1932, p. 117.

Diagnosis. - Belemnella with a large alveolar angle, 20 to 23 degrees; large Schatzky Distance, 3 to $5 \mathrm{~mm}$; well developed vascular markings; a short and coneshaped juvenile guard; vascular imprints branch off dorso-lateral double furrows posteriorly at an angle less than 40 degrees.

Discussion. - Jeletzky (1951) spelled the species name casimirovensis, as did Birkelund (1957) and some later authors. According to the International Code of Zoological Nomenclature, Article 33c, 1985, this is, however, an incorrect subsequent spelling.

The subgenus B. (Neobelemnella) has several characters which otherwise are typical for the genus Belemnitella, namely a short and cone-shaped juvenile guard and well developed vascular imprints, Moreover, the Schatzky Distance is relatively large.

Naidin (1975) placed the following taxa in synonymy with $B$. $(N$.) kazimiroviensis: Belemnitella americana Arkhangelsky, 1912, Belemnitella arkhangelskii (Naidin, 1952), Belemnitella pensaensis (Kongiel, 1962) and Belemnitella skolosdrownae (Kongiel, 1962).

Naidin (1975) suggested a late Early MaastrichtianLate Maastrichtian evolutionary lineage, which includes, in ascending order, Belemnella sumensis sumensis Naidin $1964 \mathrm{a}, B$. sumensis postsumensis Naidin, 1964a, B. sumensis praearkhangelskii Naidin, 1964a, B. sumensis kajnarensis Naidin, 1964a and Belemnella (Neobelemnella) kazimiroviensis. This lineage bridges the Early and Late Maastrichtian boundary in the eastern part of the Russian Platform. According to Schulz (1979), however, B. sumensis Naidin, 1964a is not conspecific with B. sumensis Jeletzky, 


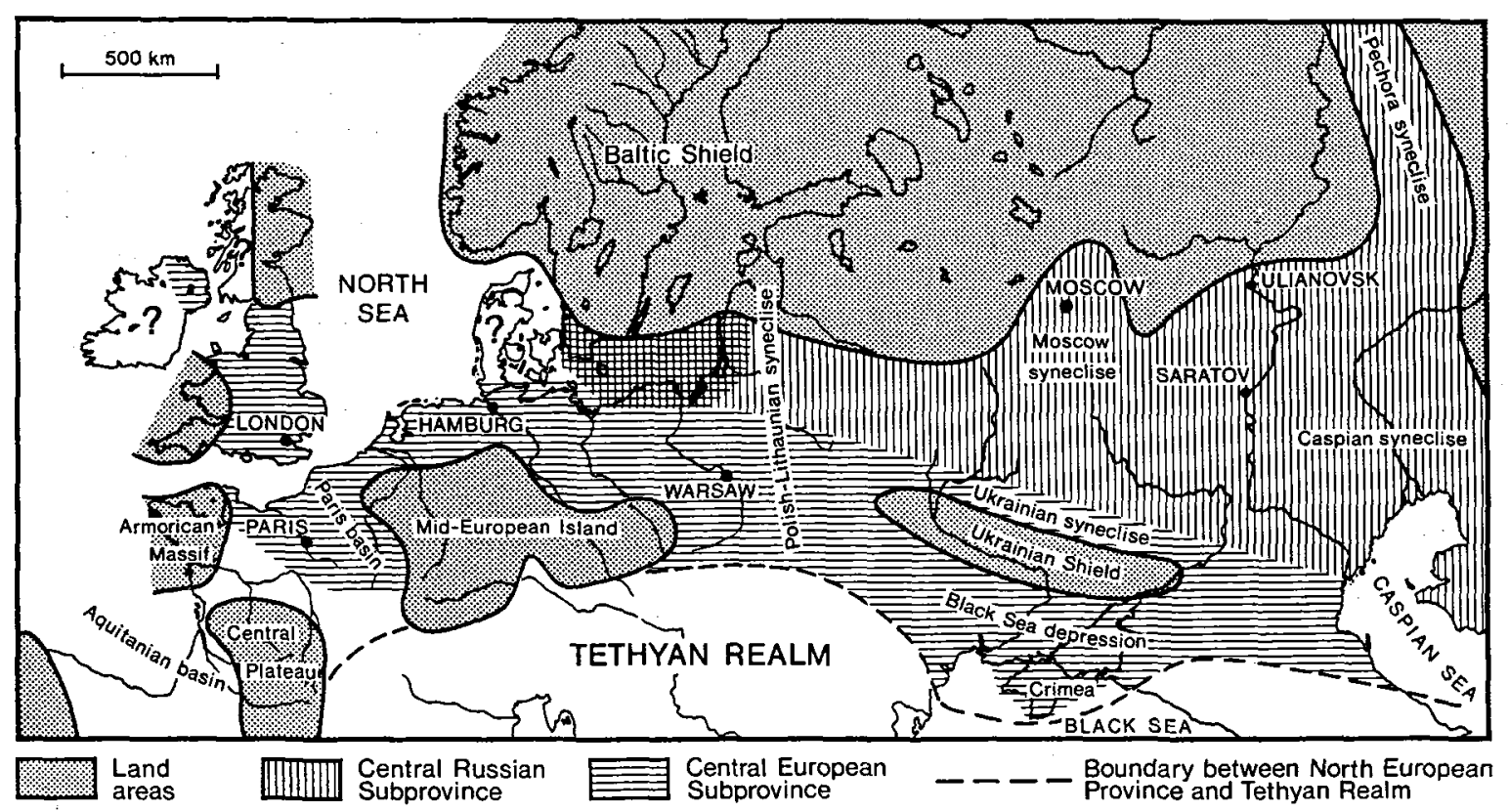

Fig. 6. Map showing the Central European and Central Russian palaeobiogeographical Subprovinces within the North European Province as defined on belemnites. A third subprovince, the Balto-Scandian Subprovince, is recognized during the Early Coniacian and latest Early Campanian-early Late Campanian. It is characterized by Goniocamax lundgreni in the Early Coniacian and the genus Belemnellocamax in the latest Early Campanian and early Late Campanian. Late Cretaceous land and sea areas represent maximum inundation for all stages. The boundaries are not reliable in detail and the biogeographic units are typically gradational in character. After Christensen (1976).

1949a, and he placed B. s. sumensis and B. sumensis postsumensis in synonymy with $B$. (B.?) praearkhangelskii.

Distribution. - This subgenus is restricted to the Late Maastrichtian (Fig. 1) and occurs in the North European Province and northern part of the Tethyan Realm. $B$. (N.) kazimiroviensis occurs in the Late Maastrichtian in the eastern part of the Russian Platform, late Late Maastrichtian in Denmark and latest Late Maastrichtian in The Netherlands (Christensen 1996).

\section{Genus Fusiteuthis Kongiel, 1962}

Type species. - By monotypy $F$. polonica Kongiel, 1962, p. 28, Pl. 1: 1-3.

Diagnosis. - Medium-sized belemnitellids with a shallow alveolus; guard lanceolate in ventral and lateral views; dorso-lateral longitudinal depressions present, guard otherwise smooth.

Discussion. - F. polonica was established on the basis of a single specimen from the latest Maastrichtian of central Poland (Pl. 2: 6-7). Later, Naidin (1973, 1975 ) recorded two specimens of $F$. sp. from the Late Maastrichtian of Crimea.
J. A. Jeletzky (unpublished MS 1972) has suggested that the genus is dubious being based on a possibly pathological specimen. I agree.

Distribution. - This genus is restricted to the latest Maastrichtian and occurs in Poland and the Crimea.

\section{Palaeobiogeography}

The belemnitellids were distributed in the North American and North European Provinces of the North Temperate Realm, in addition to the northern European margin of the Tethyan Realm (Christensen 1976, 1988, 1993b).

\section{North European Province}

This province extends from Ireland in the west to the Ural Mountains and beyond in the east (Fig. 6). The centre of origin of the belemnitellids lay there for the following reasons. They are common and all known genera and subgenera occur there, the earliest species of the family, Praeactinocamax primus, appears in the Early Cenomanian, some way above the base the substage, in this province and the earliest species of the 
Table 2. The occurrence of belemnitellid genera and subgenera in the North European and North American Provinces of the North Temperate Realm and the Tethyan Realm. Fusiteuthis is most likely a nomen dubium. The genera and subgenera are ranked with respect to their palaeobiogeographical distribution. Nine genera and two subgenera occur in the North European Province, five genera and two subgenera in the Tethyan Realm in Europe and essentially two genera in the North American Province. The numbers 1-12 refer to the first appearances of the genera and subgenera in the various palaeobiogeographical units. Detailed data are not available for the subgenera of Belemnella. 1, Early Cenomanian; 2, Late Cenomanian; 3, Middle Turonian; 4, Early Santonian; 5, latest Santonian; 6, latest Santonian-earliest Campanian; 7, Middle Coniacian; 8, Early Campanian; 9, Early Santonian; 10, Late Santonian; 11, Early Turonian; 12, latest Santonianearliest Campanian.

\begin{tabular}{lccc}
\hline Genera and subgenera & North European Province & Tethyan Realm & North American Province \\
\hline Praeactinocamax & $+^{1}$ & $+^{2}$ & $+^{3}$ \\
Belemnitella & $+^{4}$ & $+^{5}$ & $+^{6}$ \\
Belemnella (Belemnella) & + & + & + \\
Belemnella (Pachybelemnella) & + & + & \\
Belemnella (Neobelemnella) & + & $+^{8}$ & \\
Gonioteuthis & $+^{7}$ & $+^{10}$ & $(+)^{12}$ \\
Belemnellocamax & $+^{9}$ & & \\
Actinocamax & $+^{11}$ & & \\
Goniocamax & + & & \\
Belemnocamax & + & & \\
Fusiteuthis & + & & \\
\hline
\end{tabular}

other genera either occurs only there or appears earlier there than elsewhere (Table 2). The last belemnitellids became extinct at the Maastrichtian-Danian boundary. In addition to the belemnitellids, the genera Neohibolites and Parahibolites of the family Belemnopseidae also occur in this province.

The North European Province includes the Central European, Central Russian and Balto-Scandian Subprovinces (Fig. 6). The Central Russian and Central European Subprovinces are well-defined from the Middle Coniacian to the boundary between the Early and Late Campanian, a period of around $7 \mathrm{Ma}$. The two subprovinces are characterized by two independently evolving belemnite lineages: the Gonioteuthis stock inhabited the Central European Subprovince, and the Goniocamax-Belemnitella stock inhabited the Central Russian Subprovince (Christensen 1975a, 1976, $1988,1990 \mathrm{~b}$, Christensen \& Schulz in press).

The belemnite faunas of Balto-Scandia show affinity to those of the Central Russian Subprovince at certain times and to those of the Central European Subprovince at other times. However, in the Early Coniacian and latest Early Campanian and early Late Campanian a third subprovince can be recognized, named here the Balto-Scandian Subprovince. It is characterized by Goniocamax lundgreni in the Early Coniacian, Belemnellocamax mammillatus in the latest Early Campanian and $B$. balsvikensis in the early Late Campanian. B. mammillatus co-occurs with Belemnitella mucronata, Gonioteuthis quadrata scaniensis and Belemnellocamax ex gr. grossouvrei and comprises about 90-95\% of the belemnite fauna (Christensen 1975a, Table 3). B. balsvikensis co-occurs with Belem- nitella mucronata and comprises about $95 \%$ of the belemnite fauna (Christensen 1976).

At other times during the Late Cretaceous the subprovinces are less distinct, and no subprovinces can be recognized in the later part of the Late Campanian and Maastrichtian.

\section{Tethyan Realm}

Belemmnitellids occur sporadically at the northern European margin of the Tethyan Realm (Fig. 4). They have been recorded from the Late Cenomanian of the Vocontian Basin in southeastern France (Gale \& Christensen 1996), the Late Santonian-basal Early Campanian of the Corbières in the French Pyrénées (Christensen, Bilotte \& Melchior 1990, Christensen, Bilotte \& Hansotte 1993), the Late Campanian of Bulgaria (Stoyanova-Vergilova \& Jolkicev 1993) and Romania (Neagu \& Georgescu 1991), the late Late Campanian of the Northern Calcareous Alps of Austria (Christensen, submitted) and probably the Sub-Alpine Chain at Chartreuse in Savoie, southeast France (Combémorel 1996), the Early Maastrichtian of Bavaria in southern Germany (Schmid \& Schulz 1979, Schulz \& Schmid 1983a), in addition to the Campanian and Maastrichtian of Azerbaijan (Ali-Zade 1972).

There are previous records of the Early Campanian Gonioteuthis quadrata and the Late Campanian $B e$ lemnitella mucronata from the Aquitaine Basin (summarized by Séronie-Vivien 1972), but these records need to be confirmed, as do previous records of $B$. mucronata from Greece and Turkey. 


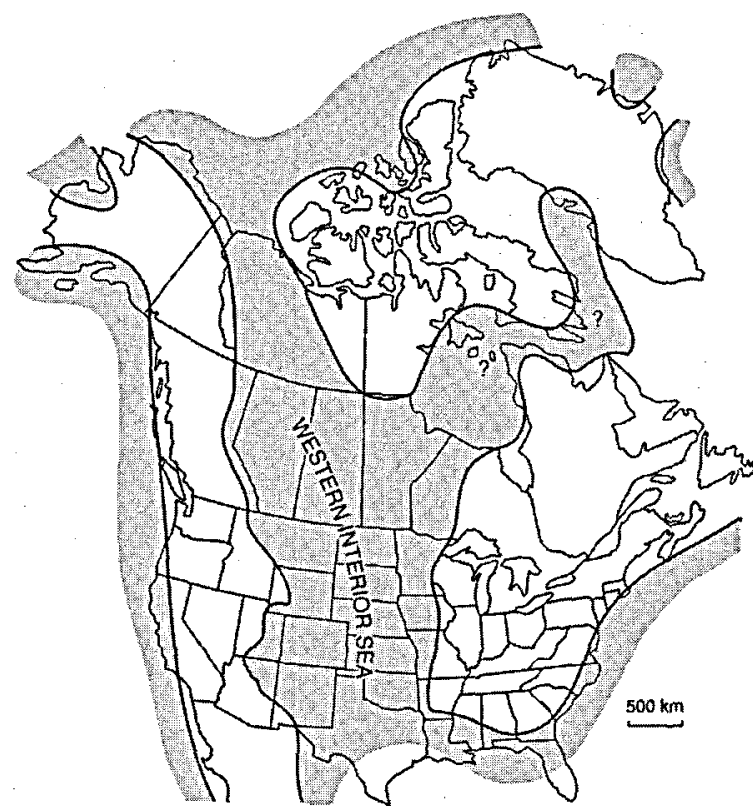

Fig. 7. Approximate distribution of land and sea in North America and Greenland during Turonian and Coniacian time. The distribution of land and sea is based on Williams \& Stelck (1975) for North America and Christensen (1993 b) for Greenland.

B. mucronata was recorded also from Austria, but this may be a misconception. $B$. hoeferi occurs in the Northern Calcareous Alps (Schloenbach 1867, Christensen, submitted; see above).

Species of the following genera and subgenera are recorded from the Tethyan Realm: Praeactinocamax, Gonioteuthis, Belemnellocamax, Belemnitella, Belemnella (Belemnella), B. (Pachybelemnella) and B. (Neobelemnella) (Fig. 4). The majority of the species occurring in the Tethyan Realm are conspecific with those from the North European Province and they thus provide a basis for correlation.

Local Late Campanian species of Belemnitella occur together with species of Belemnitella from the North European Province in Azerbaijan, Bulgaria and Romania (Ali-Zade 1972, Neagu \& Georgescu 1991, Stoyanova-Vergilova \& Jolkicev, 1993).

The middle Late Cenomanian Praeactinocamax plenus is the earliest belemnitellid recorded from the Tethyan Realm (Gale \& Christensen 1996) and belemnitellids are not recorded from the Turonian, Coniacian and Early and Middle Santonian.

\section{North American Province}

This province includes Greenland, the Western Interior of North America, in addition to the Atlantic and Gulf coasts of the USA (Fig. 7). Belemnitellids are generally very rare and belemnopseids do not occur. The belemnite faunas are essentially restricted to species of Praeactinocamax (Turonian to Early Santonian) and Belemnitella (uppermost Santonian to Maastrichtian) (Fig. 3). Actinocamax is represented only by a single specimen of $A$. verus? from central East Greenland (Jeletzky in Donovan 1954) and two specimens of $A$. aff. laevigatus from Kansas (Jeletzky 1961). However, Jeletzky (1961) suggested that the two specimens from Kansas may be juveniles of one of the large species of Praeactinocamax. The belemnite fauna of the middle Turonian seems to be rather diverse, but this may due to excessive subdivision (see above). The earliest belemnitellids from this province are Middle Turonian in age. The belemnitellids of the North American Province were discussed by Christensen (1993b).

Seibertz \& Spaeth (1995) recorded three fragmentary belemnites from the Early Turonian of northern Mexico. The anterior end with the critical characters is missing in these specimens, but, nevertheless, Seibertz \& Spaeth tentatively assigned them to Praeactinocamax cf. manitobensis. P. manitobensis occurs in the Western Interior of North America and has not been recorded previously south of Kansas (Cobban 1991). If the specimens from northern Mexico are correctly identified, which is open to discussion, then they are the most southerly belemnitellids recorded to date. Northern Mexico lay at palaeolatitude 15$20^{\circ} \mathrm{N}$.

B. americana (Morton, 1830) occurs in the Mount Laurel Formation and basal part of the Navesink Formation of the Atlantic Coastal Plain (Owens \& Sohl 1973, Fig. 4). In ammonite terms, the Mount Laurel Formation is late Late Campanian, but not latest Campanian in age (Kennedy \& Cobban 1994), and the basal part of the Navesink Formation is latest Campanian and Early Maastrichtian in age (Kennedy, Johnson \& Cobban 1995).

$B$. bulbosa occurs in the Fox Hills Formation of South Dakota, which is probably early Late Maastrichtian in age (Waage 1968, Landman \& Waage 1993). A small species of Belemnitella, probably conspecific with $B$. bulbosa, occurs in the upper part of the underlying Pierre Shale, Baculites baculus and B. clinolobatus Zones. These zones are Early but not earliest Maastrichtian in age (Kennedy \& Cobban 1993).

The majority of the belemnitellids of the North American Province are endemic, have a punctuated, strongly discontinuous stratigraphical distribution and are derived from species from the North European Province (Christensen 1993b). The endemic taxa include the Middle Turonian-Early Santonian species of Praeactinocamax and the Late Campanian-Maastrichtian species of Belemnitella. These taxa evolved from European species by allopatric speciation. Three European taxa, Actinocamax verus?, Belemnitella praecursor and $B$. ex gr. alpha/praecursor, occur in the uppermost Santonian-basal Early Campanian. 
Since most of the belemnitellid species of the North American Province are endemic intercontinental correlation based on belemnites is not possible.

\section{Mode of life of Late Cretaceous belemnites}

The belemnitellids were neritic animals restricted to the shelf. They are common in nearshore sediments, such as biocalcarenites, greensands, marls and shallow-water chalks, and populations from these sedimentary deposits characteristically contain all growth stages. They are less common to virtually absent in deeper water chalks, and populations from these deposits consist mainly of adult specimens (Christensen 1976). W.J. Kennedy (personal communication, November 1996) noted that he has never seen a single specimen in cores from the Central Graben, of which he has examined several kilometres. It therefore appears that the breeding, spawning, hatching, and, possibly for the females at least, dying grounds, were inner neritic, shallow water environments. Adult specimens from offshore, deeper water chalks may be considered as stray fully-grown individuals that died outside their normal habitat (Christensen 1976, Surlyk \& Birkelund 1977).

It is noteworthy that belemnitellids are absent or extremely rare at some horizons in the Late Campanian and Maastrichtian chalks of northwest Europe. At Kronsmoor in northwest Germany, the topmost five metres of the Late Campanian have not yielded belemnites, and Belemnella and Belemnitella are extremely rare in the basal three metres of the Maastrichtian (Schulz 1978, 1979, 1982). At Hemmoor in northwest Germany belemnites are virtually absent in the topmost five metres of the late Early Maastrichtian (only one specimen of Belemnella fastigata is recorded) and they are not recorded from the basal five metres of the early Late Maastrichtian (Schulz and Schmid 1983 b). They are virtually absent in the early Late Maastrichtian of Denmark (Surlyk 1970); only two specimens of Belemnella cf. cimbrica are recorded (Schulz and Schmid 1983b). The topmost six metres of the chalk of Hemmoor, which equates with the basal part of the late Late Maastrichtian Belemnella kazimiroviensis Zone of Denmark, have not yielded belemnites (Schulz and Schmid 1983b).

The belemnitellids were stenothermal animals adapted to life in warm-temperate waters according to the palaeotemperature curves by Jenkyns, Gale \& Corfield (1994, Fig. 12; Cenomanian to Santonian of east Kent) and Schönfeld \& Schulz (1996, Fig. 4; Late Campanian to Early Maastrichtian of northern Germany). These areas were situated at about palaeolatitude $40^{\circ} \mathrm{N}$. According to Jenkyns et al. the palaeotemperature was about $21^{\circ} \mathrm{C}$ in the basal Cenomanian, increased gradually to a maximum of about $28^{\circ} \mathrm{C}$ at the Cenomanian-Turonian boundary and declined irregularly thereafter. It was about $22^{\circ} \mathrm{C}$ in the Coniacian and dropped to around $19^{\circ} \mathrm{C}$ in the Late Santonian. Following Schönfeld \& Schulz the palaeotemperature was about $15^{\circ} \mathrm{C}$ in the early Late Campanian, increased to about $17^{\circ} \mathrm{C}$ in the earliest Maastrichtian and decreased to around $15^{\circ} \mathrm{C}$ in the middle Early Maastrichtian.

The South Temperate dimitobelids were also stenothermal shallow-water dwellers (Doyle \& Howlett 1989), but they appear to be adapted to life in cooler waters than the belemnitellids. Pirrie \& Marshall (1990) and Crame, Lomas, Pirrie \& Luther (1996) suggested that the maximum surface water temperature was about $20^{\circ} \mathrm{C}$ in the Turonian-Coniacian and declined thereafter. It was about $14^{\circ} \mathrm{C}$ in the Santonian and Campanian and about $12^{\circ} \mathrm{C}$ in the Maastrichtian of James Ross Island, Antarctica (palaeolatitude 60$65^{\circ} \mathrm{S}$ ).

Since both the belemnitellids and dimitobelids were shallow-water dwellers, oceans with deep water may have acted as physical barriers and precluded spread of these families. Warm tropical waters in the Tethyan Realm may also have acted as a physical barrier for these families.

The belemnopseids Neohibolites and Parahibolites were widely distributed in the Albian-Cenomanian, from the Central European Subprovince of the North Temperate Province, across the Tethyan Realm to the South Temperate Province, and have been recorded from deep marine and continental slope deposits, as well as inner neritic sediments. The habitat of these genera may therefore have been surface oceanic, but they probably spent their breeding season inshore (Doyle \& Howlett 1989). They were eurythermal, adapted to life in warm temperate as well as tropical waters.

\section{Belemnitellid distribution}

Praeactinocamax and Belemnitella are more widely distributed than the remaining genera and subgenera and occur in both the North European and North American Provinces, as well as in northern European part of the Tethyan Realm (Table 2). Gonioteuthis, Belemnellocamax and Belemnella are distributed in both the North European Province and the Tethyan Realm. Actinocamax, Belemnocamax and Goniocamax occurs only in the North European Province, except for a single specimen of $A$. verus? from East Greenland (see above), but they have different distribution patterns. Actinocamax is widely distributed in the North European Province, Goniocamax is mainly restricted to the Central Russian Subprovince and Balto-Scandia and Belemnocamax occurs only in northwest Germany and eastern England. Thus, the genera and subgenera can be ranked in the following way with respect to their 


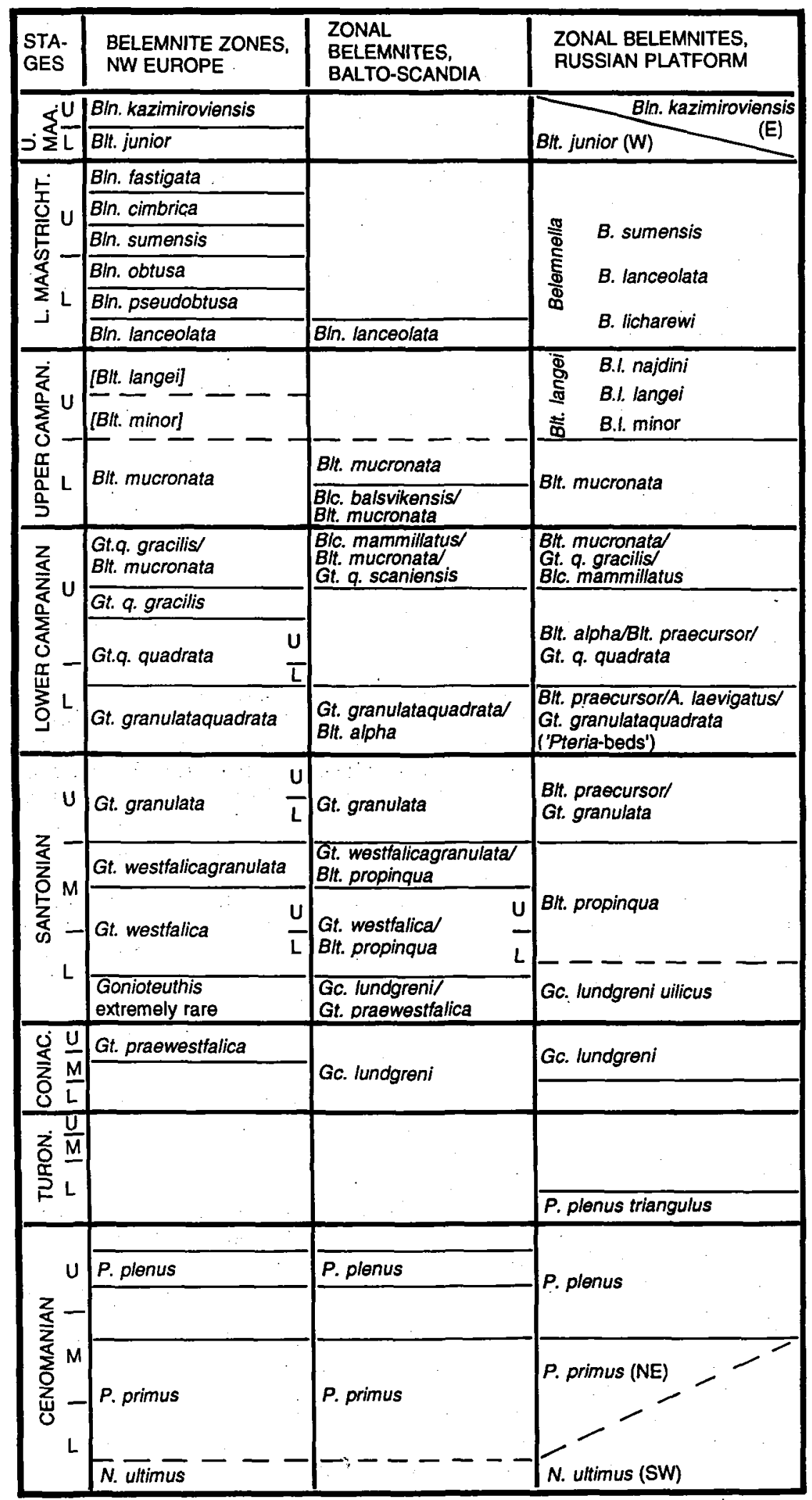

Fig. 8. Late Cretaceous belemnite stratigraphy of northwest Europe, BaltoScandia and the Russian Platform. In order to ease reading of the diagram the following abbreviations are used for the genera.

$P .=$ Praeactinocamax A. $=$ Actinocamax; Blt. $=$ Belemnitella; Bln. $=$ Belemnella; Blc. $=$ Belemnellocamax Gt. = Gonioteuthis; Gc. $=$ Goniocamax $N .=$ Neohibolites . Vertical axis not to scale. Modified from Christensen (1986). 
palaeogeographical distribution, from the largest to the smallest areal extent (Table 2):

(1) Praeactinocamax and Belemnitella; (2) Gonioteuthis, Belemnellocamax and Belemnella; (3) Actinocamax; (4) Goniocamax; (5) Belemnocamax.

The palaeogeographical distribution of the belemnitellids was controlled by a number of factors, including sea-level changes, temperature, palaeocurrents, ecological tolerance and competition. Gale \& Christensen (1996) suggested that the southwards migration of Praeactinocamax plenus into the Tethyan Realm in the Late Cenomanian was due to a significant fall of sea temperature, the so-called Plenus Cold Event, working in concert with the development of suitable shallow water habitats. In addition, lack of competition of the Tethyan belemnopseids, which disappeared in the Middle Cenomanian, may also have been of importance. Christensen (1976) suggested that the parallel evolution of the Gonioteuthis and Goniocamax-Belemnitella stocks from the Middle Coniacian to the boundary between the Early and Late Campanian in the adjacent Central European and Central Russian Subprovinces, respectively, was due to mutual competition. The causes of the palaeogeographical distribution and migrations of the belemnitellids will be discussed in more detail in a forthcoming paper.

\section{Late Cretaceous belemnite extinctions}

The last genera of the Tethyan belemnopseids, Parahibolites and Neohibolites, became extinct worldwide in the Middle Cenomanian. The last dimitobelid belemnites in the South Temperate Realm, Dimitobelus (Dimitocamax) seymourensis Doyle, 1988 and D. (D.) hectori Stevens, 1965, disappeared in the early Maastrichtian (Doyle \& Zinsmeister 1988, Doyle \& Howlett 1989, Crame, Lomas, Pirrie \& Luther 1996).

The belemnitellids suffered three extinctions during the Late Cretaceous: (1) in the Middle Cenomanian-earliest Early Turonian, (2) around the Early and Late Campanian boundary and (3) at the Maastrichtian-Palaeocene boundary. At the first extinction event, the belemnitellids Belemnocamax boweri and Praeactinocamax plenus of the P. primus-plenus lineage disappeared along with the belemnopseids. After this extinction the belemnitellids are extremely rare in the Turonian and early Coniacian of the Central European Subprovince and have a very restricted distribution in the Central Russian Subprovince (Christensen 1982). It appears that the belemnitellids retreated into refugia in the Turonian, which may be situated in the Central Russian Subprovince. The Central European Subprovince was repopulated by Gonioteuthis praewestfalica in the late Coniacian and belemnitellids did not invade the Tethyan Realm again until the Late Santonian.

The next extinction event occurred in the latest Early Campanian and early Late Campanian. Three genera disappeared, Actinocamax, Gonioteuthis and Belemnellocamax, and only one genus, Belemnitella, survived. After this extinction, Belemnitella expanded its area of distribution to cover the entire North European Province, where it is common. It also invaded the Tethyan Realm. However, only one species, $B$. mucronata, occurs in the lower part of the early Late Campanian (Fig. 2), that is a period of about $1.5 \mathrm{Ma}$.

The last extinction occurred at the CretaceousPalaeocene boundary and no belemnites survived. Paleogene belemnites have been recorded earlier. However, the Eocene Bayanoteuthis rugifer Schloenbach, 1868, which occurs in southern Europe, has been reinterpreted as a pennetulacean coral (Riegraf 1991) and others are considered to be sepiids with a belemnite-like guard (Doyle, Donovan \& Nixon 1994).

\section{Late Cretaceous belemnite biostratigraphy of Europe}

The belemnitellids are of fundamental importance in biostratigraphy and correlation of the Late Cretaceous of the North European Province, particularly during the Coniacian to Maastrichtian stages. They are common, widely distributed there and the fossilization potential is high (Christensen 1990b, 1996). 25 zones have been established in northwest Europe and a little less on the Russian Platform (Fig. 8).

The zonation of the west Europe and the Russian Platform is based upon the belemnopseid Neohibolites ultimus and species of Praeactinocamax for the Cenomanian, species of Belemnitella for the Late Campanian, species of Belemnella for the Early Maastrichtian and species of Belemnitella and Belemnella for the Late Maastrichtian. In the Middle Coniacian to Early Campanian the zonation of northwest Europe is based upon species of Gonioteuthis, while it is based upon species of Goniocamax and Belemnitella on the Russian Platform (Fig. 8).

The Middle Coniacian to Early Campanian belemnite faunas of Balto-Scandia are of great importance, because they include species of both the Gonioteuthis and Goniocamax-Belemnitella stocks, and thus provide a basis for correlation between the two subprovinces (Fig. 8)

Belemmnitellids are extremely rare in the Turonian and early Coniacian of northwest Europe (Christensen 1982) and, consequently, no zones have been established. Christensen $(1995,1996)$ argued that the conventional late Late Campanian Belemnitella minor and $B$. langei Zones of Jeletzky (1951) should not be maintained. These zones are therefore placed in square brackets in Figure 8. 


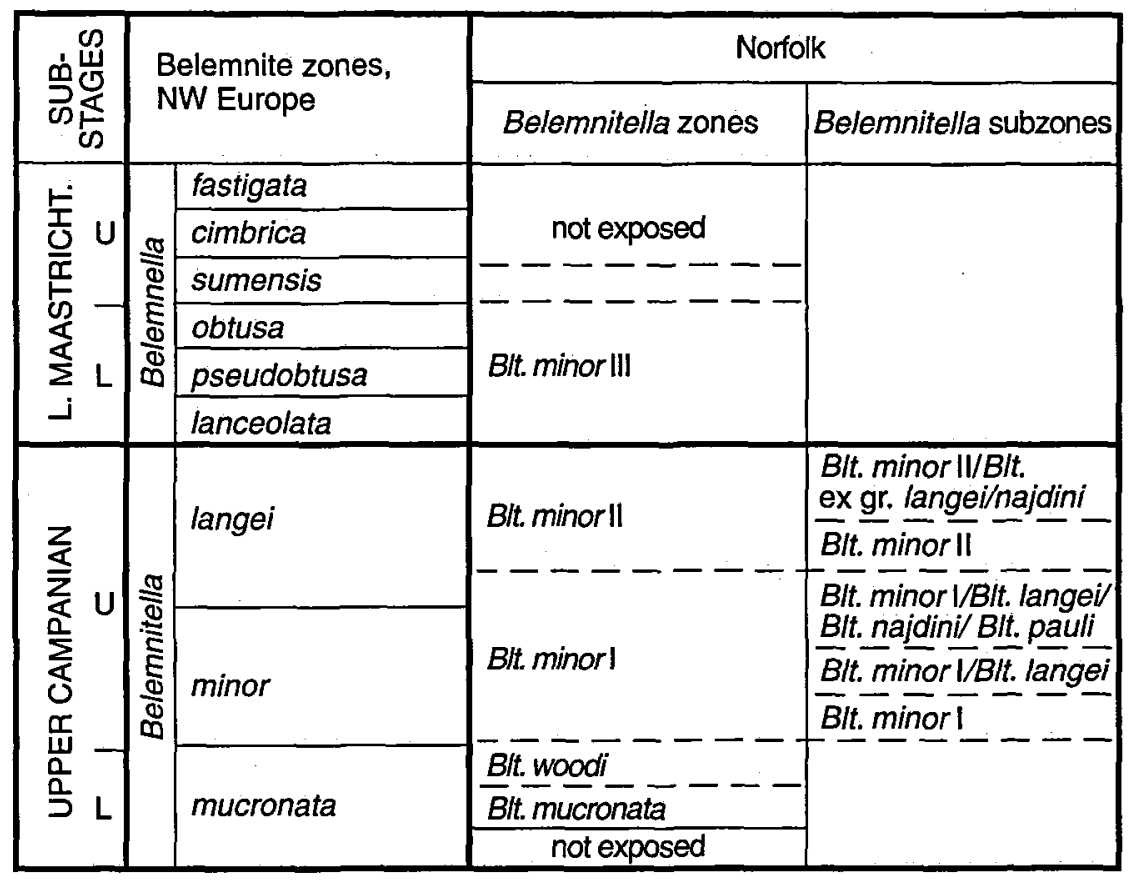

Fig. 9. Stratigraphical correlation diagram showing Late Campanian Belemnitella zones (Jeletzky 1951) and Early Maastrichtian Belemnella zones (Schulz 1979), in addition to Belemnitella zones and subzones of Norfolk (Christensen 1995). Blt. $=$ Belemnitella . Vertical axis not to scale. After Christensen (1996).

Some of the belemnite zones have been subdivided. For instance, Christensen $(1995,1996)$ subdivided the Late Campanian of Norfolk into four informal zones on the basis of large to very large species of Belemnitella (Fig. 9). These are in ascending order: the $B$. mucronata, $B$, woodi, B. minor I and B. minor II zones. The $B$. minor zones were subdivided into five informal subzones, mainly on the basis of small species of Belemnitella, B. langei, B. najdini and B. ex gr. langei/ najdini. Further studies are necessary to see if these zones can be extended to other areas in Europe. Keutgen (1995) has shown subsequently that the zonation of Norfolk is applicable in northeast Belgium.

Christensen \& Schulz (in press) subdivided the Coniacian and Lower Santonian of Bornholm, Denmark into three zones: the Coniacian Goniocamax lundgreni Zone, the early Early Santonian Gonioteuthis praewestfalica Zone and the late Early Santonian Gonioteuthis westfalica Zone (Fig. 10). These zones were subdivided into eight assemblage zones. However, it is very likely that the zones and assemblage zones are applicable only in Balto-Scandia for the following reasons. Some of the index species are very rare or not recorded from the Central European Subprovince (Goniocamax lundgreni, Belemnitella schmidi and B. propinqua), others are not recorded from the Central Russian Subprovince (Gonioteuthis praewestfalica, G. westfalica and G. ernsti), and Goniocamax birkelundae and G. striatus are not recorded outside Bornholm. Moreover, G. lundgreni occurs earlier on Bornholm (Early Coniacian) than in the Central Russian Subprovince (Middle Coniacian), and G. praewestfalica is late Coniacian in age in the Central European Subprovince, while it is early Early Santonian in age on Bornholm.

\section{Acknowledgments}

I thank the journal referees, Prof. W. J. Kennedy, Oxford, and Dr. P. Doyle, London for constructive criticism of the manuscript. I also thank the staff of the Geological Museum, Copenhagen for technical support.

\section{Dansk sammendrag}

Belemnit familien Belemnitellidae forekommer kun i $\emptyset v r e$ Kridt på den nordlige halvkugle, fra Nedre Cenomanien til Øvre Maastrichtien. Den inkluderer følgende slægter og underslægter: Praeactinocamax, Actinocamax, Belemnocamax, Gonioteuthis, Belemnellocamax, Goniocamax, Belemnitella, Belemnella (Belemnella), Belemnella (Pachybelemnella), Belemnella (Neobelemnella) og den dubiøse Fusiteuthis.

Antallet af slægter og underslægter varierer gennem $\emptyset$ vre Kridt. Det er en til to i Cenomanien og stiger gradvist til seks i Nedre Santonien. Det aftager derefter gradvist til en gennem det meste af $\emptyset$ vre Campanien og tiltager til to til tre i Maastrichtien.

Det evolutionære center for belemnitelliderne lå i 


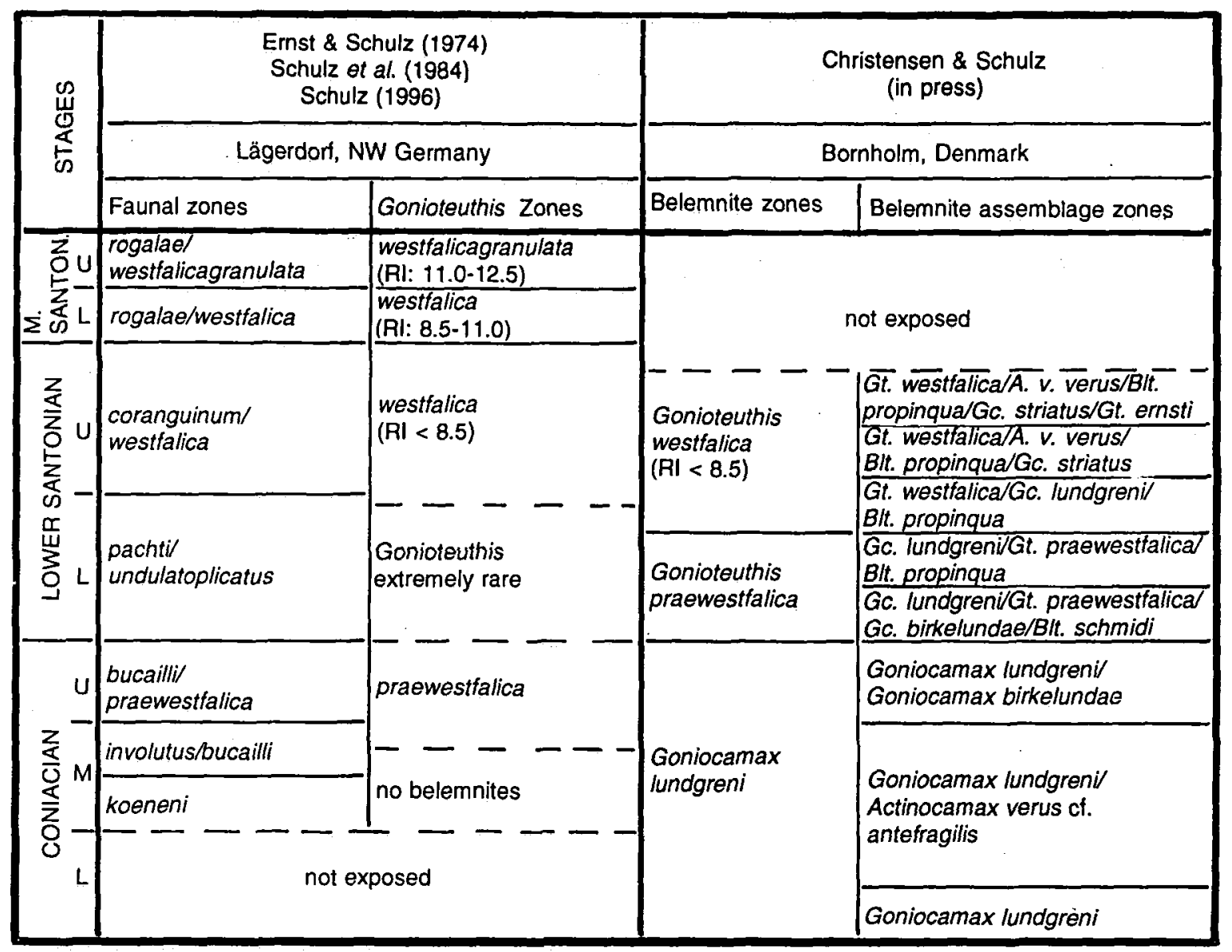

Fig. 10. Stratigraphical correlation diagram of the Coniacian and Santonian, showing faunal and Gonioteuthis zones of Lägerdorf and belemnite zones and assemblage zones of Bornholm. Gc. = Goniocamax; Gt. = Gonioteuthis; Blt. = Belemnitella; A. = Actinocamax. Vertical axis not to scale. Modified from Christensen \& Schulz (in press).

den Nordeuropæiske Provins, hvor alle kendte slægter og underslægter forekommer. Den første art inden for familien, Praeactinocamax primus, er fra Nedre Cenomanien og kendes kun fra denne provins. Belemnitelliderne udvandrede fra den Nordeuropæiske Provins til henholdsvis den Nordamerikanske Provins og Tethys Området. Arter af fem slægter og to underslægter findes i Tethys Området, og hovedparten af disse er identiske med arter fra den Nordeuropæiske Provins. Den tidligste art er fra $\emptyset v r e$ Cenomanien. Arter af hovedsagelig to slægter forekommer i den Nordamerikanske Provins og hovedparten af disse er endemiske. De tidligste arter er fra Mellem Turonien.

\section{References}

Andreae, A. 1895. Ein neuer Actinocamax aus der Quadratenkreide von Braunschweig. Mitteilungen aus dem Roemer-Museum Hildesheim 2, 4 pp.

Ali-Zade, A. A. 1972. Cretaceous belemnites of Azerbaijan. 279 pp. Moscow: 'Nedra' Publishing House. [In Russian.]

Arkhangelsky, A. D. 1912. The Upper Cretaceous deposits in the eastern part of the Europen Russia. Materialy dlya Geologii Rossii 25, 631 pp. [In Russian.]

Bandel, K. \& Spaeth, C. 1988. Structural differences in the ontogeny of some belemnite rostra. In Wiedmann, J. \& Kullmann, J. (eds) Cephalopods - Present and Past, 247-271. Stuttgart: Schweizerbart'sche Verlagsbuchhandlung.

Bather, F.A. 1888. Shell-growth in Cephalopoda (Siphonopoda). Annals and Magazine of Natural History (6), 1, 298-310.

Bayle, E. 1878. Fossiles principaux des terrains de la France. Explication de la Carte Géologique de la France 4(1), Atlas, 79 plates. 
Birkelund, T. 1956. Upper Cretaceous belemnites from West Greenland. Meddelelser om Grønland 137, 30 pp. Birkelund, T. 1957. Upper Cretaceous belemnites of Denmark. Biologiske Skrifter. Det Kongelige Danske Videnskabernes Selskab 9,69 pp.

Blainville, H. M. D. de 1825-1827. Manual de Malacologie et de Conchyliologie. 664 pp. (1825), 87 plates (1827). Paris: Levrault.

Blainville, H. M. D. de 1827: Mémoire sur les Belemnites, considerées zoologiquement et géologiquement. $136 \mathrm{pp}$. Paris: Levrault.

Brotzen F. 1960. The Mesozoic of Scania, Southern Sweden. International Geological Congress, XXI Session, Norden 1960, Guide to Excursions A 21 and C 16, 15 pp.

Bülow-Trümmer, E. von 1920. Fossilium Catalogus. I: Animalia. Pars 11: Cephalopoda dibranchiata. 313 pp. Berlin: Junk.

Christensen, W. K. 1971. Belemnitella propinqua propinqua (Moberg, 1885) from Scandinavia. Bulletin of the Geological Society of Denmark 13, 285-293.

Christensen, W. K. 1972. Structure of the guard in a species of Belemnitella. Neues Jahrbuch für Geologie und Paläontologie, Monatshefte 6, 321-330.

Christensen, W. K. 1973. The belemnites and their stratigraphical significance. In Bergström, J., Christensen, W. K., Johansson, C. \& Norling, E.: An extension of Upper Cretaceous rocks to the Swedish west coast at Särdal. Bulletin of the Geological Society of Denmark 22, 113140.

Christensen, W. K. 1974. Morphometric analysis of Actinocamax plenus from England. Bulletin of the Geological Society of Denmark 23, 1-26.

Christensen, W. K. 1975a. Upper Cretaceous belemnites from the Kristianstad area in Scania. Fossils and Strata $7,69 \mathrm{pp}$

Christensen, W. K. 1975b. Designation of lectotypes for Gonioteuthis westfalicagranulata and $G$. granulataquadrata. Paläontologische Zeitschrift 49, 126-134.

Christensen, W. K. 1976. Palaeobiogeography of Late Cretaceous belemnites of Europe. Paläontologische Zeitschrift 50, 113-129.

Christensen, W. K. 1982. Late Turonian-early Coniacian belemnites from western and central Europe. Bulletin of the Geological Society of Denmark 31, 63-79.

Christensen, W. K. 1986. Upper Cretaceous belemnites from the Vomb Trough in Scania, Sweden. Sveriges Geologiska Undersökning Ca57, $57 \mathrm{pp}$.

Christensen, W. K. 1988. Upper Cretaceous belemnites of Europe: State of the art. In Streel, M. \& Bless, M.J.M. (eds) The Chalk District of the Euregio Meuse-Rhine, 5-16. Maastricht: Natuurhistorisch Museum, Maastricht and Liège: Laboratoires de Paléontologie de l'Université d'Etat.

Christensen, W. K. 1990a. Actinocamax primus Arkhangelsky (Belemnitellidae; Upper Cretaceous): Biometry, comparison and biostratigraphy. Paläontologische Zeitschrift 64, 75-90.

Christensen, W. K. 1990b. Upper Cretaceous belemnite stratigraphy of Europe. Cretaceous Research 11, 371386.

Christensen, W. K. 1991. Belemnites from the Coniacian to Lower Campanian chalks of Norfolk and southern England. Palaeontology 34, 695-749.
Christensen, W. K. 1993a. Upper Cretaceous belemnitellids from the Båstad Basin, southern Sweden. Geologiska Föreningens i Stockholm Förhandlingar 115, 39-57.

Christensen, W. K. 1993b. Actinocamax cobbani n. sp. from the Coniacian of Montana and Wyoming and the occurrence of Late Cretaceous belemnites in North America and Greenland. Journal of Paleontology 67, 434-446.

Christensen, W. K. 1993c. Belemnocamax boweri Crick, an unusual belemnite from the Cenomanian of northwest Germany and eastern England. Bulletin of the Geological Society of Denmark 40, 157-166.

Christensen, W. K. 1994. Upper Cretaceous belemnites from Lonzée (SE Belgium) and their stratigraphic significance. Bulletin de l'Institut Royal des Sciences Naturelles de Belgique, Sciences de la Terre 64, 151-158.

Christensen, W. K. 1995. Belemnitella faunas from the Upper Campanian and Lower Maastrichtian chalk of Norfolk, England. Special Papers in Palaeontology 51, $84 \mathrm{pp}$.

Christensen, W. K. 1996. A review of the Upper Campanian and Maastrichtian belemmnite biostratigraphy of Europe. Cretaceous Research 17, 751-766.

Christensen, W. K. (submitted). Belemnitella hoeferi Schloenbach from the Late Campanian of the Gschliefgraben area, Austria. Beiträge zur Paläontologie.

Christensen, W. K., Bilotte, M. \& Hansotte, M. 1993. Additional Late Cretaceous belemnitellids from the Corbières, French Pyrénées and the ammonite biostratigraphy of the Santonian. Cretaceous Research 14, 101-106.

Christensen, W. K., Bilotte, M. \& Melchior, M. 1990. Upper Cretaceous belemnitellids from the Corbiéres, French Pyrénées. Cretaceous Research 11, 359-369.

Christensen, W. K. \& Hoch, E. 1983. Actinocamax cf. manitobensis from the Kangerdlugssuaq area, southern East Greenland. Bulletin of the Geological Society of Denmark 32, 33-42.

Christensen, W. K. \& Schmid, F. 1987. The belemnites of the Vaals Formation from the C. P. L. Quarry at Hallembaye in Belgium - Taxonomy, biometry and biostratigraphy. Geologisches Jahrbuch A94, 3-37.

Christensen, W. K. \& Schulz, M.-G. (in press). Coniacian and Santonian belemnite faunas from Bornholm, Denmark. Fossils and Strata.

Cobban, W. A. 1991. Occurrence and significance of the Middle Turonian (Upper Cretaceous) belemnite Actinocamax in central western Montana. U.S. Geological Survey Bulletin 1962, 21-26.

Combémorel, R. 1996. Figuration d'une petite fauna de bélemnites du Crétacé supérieur de Chartreuse (Chaînes Supalpines, France). Mitteilungen aus dem GeologischPaläontologischen Institut der Universität Hamburg 77 , 159-164.

Combémorel, R., Christensen, W. K., Naidin, D. P. \& Spaeth, C. 1981. Les Bélemnites. Cretaceous Research 2, 283-286.

Crame, J. A., Lomas, S. A., Pirrie, D. \& Luther, A. 1996. Late Cretaceous extinction patterns in Antarctica. Journal of the Geological Society London 153, 503-506.

Crick, G. C. 1907. Note on two rare forms of Actinocamax from the English Upper Chalk. Geological Magazine 4, 389-395.

Crick, G. C. 1910. On Belemnocamax boweri, n.g. et sp. A new cephalopod from the Lower Chalk of Lincolnshire. Proceedings of the Geologists' Association 21, 360-365. 
Cuvier, G. 1795. Second Mémoire sur l'organisation et les rapports des Animaux à sang blanc, dans lequel on traite de la structure des Mollusques et de leur division en ordres. Magasin Encyclopédique ou Journal des Sciences, des Lettres et des Arts 2, 433-449.

Donovan, D. T. 1954. Upper Cretaceous fossils from Traill and Geographical Society Øer, East Greenland. Meddelelser om Grønland 72, $33 \mathrm{pp}$.

Doyle, P. 1985. 'Indian' belemnites from the Albian (Lower Cretaceous) of James Ross Island, Antarctica: British Antarctic Survey Bulletin 69, 23-34.

Doyle; P. 1987a. The Cretaceous Dimitobelidae (Belemnitida) of the Antarctic peninsula region. Palaeontology 30, 147-177.

Doyle, P. 1987b. Early Cretaceous belemnites from southern Mozambique. Palaeontology 30, 311-317.

Doyle, P. 1988. The belemnite family Dimitobelidae in the Cretaceous of Gondwana. In Wiedmann, J. \& Kullmann, J. (eds) Cephalopods - Present and Past, 539-552. Stuttgart: Schweizerbart'sche Verlagsbuchhandlung.

Doyle, P. 1990. New records of dimitobelid belemnites from the Cretaceous of James Ross Island, Antarctica. Alcheringa 14, 159-175.

Doyle, P. 1992. A review of the biogeography of Cretaceous belemnites. Palaeogeography, Palaeoclimatology, Palaeoecology 92, 207-216.

Doyle, P., Donovan, D. T. \& Nixon, M. 1994. Phylogeny and systematics of the Coleoidea. The University of Kansas Paleontological Contributions 5, 15 pp.

Doyle, P. \& Howlett, P. 1989. Antarctic belemnite biogeography and the break-up of Gondwana. In Crame, J. A. (ed.) Origins and Evolution of the Antarctic Biota. Geological Society Special Publication 47, 167-182.

Doyle, P. \& Zinsmeister, W. J. 1988. A new dimitobelid belemnite from the Upper Cretaceous of Seymour Island, Antarctic Peninsula. Geological Society of America Memoir 169, 285-290.

Ernst, G. 1964. Ontogenie, Phylogenie und Stratigraphie der Belemnitengattung Gonioteuthis Bayle aus dem nordwestdeutschen Santon/Campan. Fortschritte in der Geologie von Rheinland und Westfalen 7, 113-174.

Ernst, G. 1966. Fauna, Ökologie und Stratigraphie der mittelsantonen Schreibkreide von Lägerdorf (SW Holstein). Mitteilungen aus dem Geologischen Staatsinstitut in Hamburg 35, 115-150.

Ernst, G. 1968. Die Oberkreide-Aufschlüsse im Raume Braunschweig-Hannover und ihre stratigraphische Gliederung mit Echinodermen und Belemniten. 1. Teil: Die jüngere Oberkreide (Santon-Maastricht). Beihefte zu den Berichten der Naturhistorischen Gesellschaft zu Hannover 5, 235-284.

Ernst, G. \& Schulz, M.-G. 1974. Stratigraphie und Fauna des Coniac und Santon im Schreibkreide-Richtprofil von Lägerdorf (Holstein). Mitteilungen aus dem GeologischPaläontologischen Institut der Universität Hamburg 43, 5-60.

Fritsch, A. \& Schlönbach, U. 1872. Cephalopoden der böhmischen Kreideformation. 52 pp. Prag: Verlag des Verfassers.

Gale, A. S. \& Christensen, W. K. 1996. Occurrence of the belemnite Actinocamax plenus in the Cenomanian of SE France and its significance. Bulletin of the Geological Society of Denmark 43, 68-77.

Glazunova, A. E. 1972. The paleontological basis for stratigraphical subdivision for the Cretaceous deposits of the Volga region; Upper Cretaceous. $203 \mathrm{pp}$. Ministry of the Geology of the USSR. Geological Institute VSEGEI. [In Russian.]

Harland, W. B., Armstrong, R. L., Cox, A. V., Craig, L. E., Smith, A. G. \& Smith, D. G. 1989. A geologic time scale 1989. 263 pp. Cambridge: Cambridge University Press.

Herrmannsen, A. N. 1846. Indices Generum Malacozoorum. Primordia 1. $636 \mathrm{pp}$. Cassellis.

Hyatt, A. 1884. Fossil Cephalopoda in the Museum of Comparative Zoology. Proceedings of the American Association for the Advancements of Science 32, 323-361.

International Commission on Zoological Nomenclature 1985. Opinion 1328. Belemnites mucronatus Schlotheim, 1813 (Coleoidea): Conserved and neotype designated. Bulletin of Zoological Nomenclature 42, 222-225.

Jagt, J. M. M., Deckers, M., Dhondt, A. V., Dortangs, R. W. et al. (11 other authors) 1995. Preliminary report of field work at Altembroeck (NE Belgium, Early Maastrichtian). Belgische Geologische Dienst, Professional Paper 1995/1, 276, $20 \mathrm{pp}$.

Jagt, J. W. M., Kennedy, W. J., Burnett, J. A., Christensen, W. K. \& Dhondt, A. V. 1995. Santonian macrofauna and nannofossils from northeast Belgium. Bulletin de 1'Institut Royal des Sciences Naturelles de Belgique, Sciences de la Terre 65, 127-137.

Janet, C. 1891. Note sur trois nouvelles bélemnites sénoniennes. Bulletin de la Société Géologique de France 19, 716-721.

Jarvis, I. 1980. Palaeobiology of Upper Cretaceous belemnites from phosphatic chalk of the Anglo-Paris Basin. Palaeontology 23, 889-914.

Jeletzky, J. A. 1941. Über die Systematik und die Phylogenie der Belemniten der Oberen Kreide. Doklady̆ Akademii Nauk SSSR 2, 23-30. [In Ukrainian and German.]

Jeletzky, J. A. 1946. Zur Kenntnis der Oberkretazischen Belemniten. Geologiska Föreningens Förhandlingar i Stockholm 68, 87-105.

Jeletzky, J. A. 1949a. Über den taxonomischen Wert einiger morphologischen Elemente des Rostrums der belemnitellenartigen Formen (Familie Belemnitellidae Pavlow, 1913), sowie über die Gattung Belemella (Nowak, 1913, subgenus) Jeletzky, 1941, ihre Phylogenie und einige Vertreter. Neues Jahrbuch für Mineralogie, Geologie und Paläontologie, Monatshefte 9, 257-287.

Jeletzky, J. A. 1949b. Some notes on "Actinocamax" propinquus Moberg 1885, its taxonomic position and phylogenetic relations within the family Belemnitellidae Pavlov 1913, morphological characters and synonymy. Geologiska Föreningens i Stockholm Förhandlingar 71, 415424.

Jeletzky, J. A. 1950. Actinocamax from the Upper Cretaceous of Manitoba. Geological Survey of Canada Bulletin $15,41 \mathrm{pp}$.

Jeletzky, J. A. 1951. Die Stratigraphie und Belemnitenfauna des Obercampan und Maastricht Westfalens, Nordwestdeutschlands und Dänemarks, sowie einige allgemeine Gliederungs-Probleme der jüngeren borealen Oberkreide Eurasiens. Beihefte Geologisches Jahrbuch 1, 142 pp.

Jeletzky, J. A. 1955. Evolution of Santonian and Campanian Belemnitella and paleontological systematics: exemplified by Belemnitella praecursor Stolley. Journal of $\mathrm{Pa}-$ leontology 29, 478-509.

Jeletzky, J. A. 1961. Actinocamax from the Upper Cretaceous Benton and Niobrara Formations of Kansas. Journal of Paleontology 35, 505-531. 
Jeletzky, J. A. 1965. Taxonomy and phylogeny of fossil Coleoidea (= Dibranchiata). Geological Survey of Canada, Paper 65-2, 42, 72-76.

Jenkyns, H. H., Gale, A. S. \& Corfield, R. M. 1994. Carbon- and oxygen-isotope stratigraphy of the English Chalk and Italian Scaglia and its palaeoclimatic significance. Geological Magazine 131, 1-34.

Kennedy, W. J. \& Cobban, W. A. 1993. Ammonites from the Saratoga Chalk (Upper Cretaceous), Arkansas. Journal of Paleontology 67, 404-434.

Kennedy, W. J. \& Cobban, W. A. 1994. Upper Campanian ammonites from the Mount Laurel Sand at Biggs farm, Delaware. Journal of Paleontology 68, 1285-1305.

Kennedy, W. J., Johnson, R. O. \& Cobban, W. A. 1995. Upper Cretaceous ammonite faunas of New Jersey. The Geological Association of New Jersey 12, 24-55.

Keutgen, N. 1995. Late Campanian Belemnitella from the Zeven Wegen Member (Gulpen Formation) at the CPL quarry (Haccourt, NE Belgium). Second International Symposium on Cretaceous Stage Boundaries, Brussels, Abstract Volume, p. 176.

Keutgen, N. \& van der Tuuk, L. A. 1990. Belemnites from the Lower Maastrichtian of Limburg, Aachen and Liège. Mededelingen Rijks Geologische Dienst 44, 39 pp.

Kongiel, R. 1962. On belemnites from the Maastrichtian, Campanian and Santonian sediments in the Middle Vistula Valley (Central Poland). Prace Muzeum Ziemi $5,148 \mathrm{pp}$.

Landmann, N. H. \& Waage, K. M. 1993. Scaphitid ammonites of the Upper Cretaceous (Maastrichtian) Fox Hill Formation in South Dakota and Wyoming. Bulletin of the American Museum of Natural History 215, $257 \mathrm{pp}$.

Makhlin, V.Z. 1965. New Late Turonian Goniocamax of the Volga area. Paleontologicheskii Zhurnal 4, 26-32. [In Russian.] [Translation in Paleontological Journal $1965,4,26-32]$.

Miller, J. S. 1823: Observations on the genus Actinocamax. Transactions of the Geological Society, (2), 2, 45-62.

Mitchell, S. F. 1994. New Data on the biostratigraphgy of the Flamborough Chalk Formation (Santonian, Upper Cretaceous) between South Landing and Danes Dyke, North Yorkshire. Proceedings of the Yorkshire Geological Society 50, 113-118.

Mitchell, S. F. 1995. Uintacrinus anglicus Rasmussen from the Upper Cretaceous Flamborough Chalk Formation of Yorkshire: implications for the position of the SantonianCampanian boundary. Cretaceous Research 16, 745-756.

Moberg, J. C. 1885. Cephalopoderna i Sveriges kritsystem. II. Artsbeskrifning. Sveriges Geologiska Undersökning C73, $65 \mathrm{pp}$.

Montfort, D. de 1808. Conchyoliogie systêmatique et classification méthodique des coquilles. I. Coquilles univalves, cloisonées. 410 pp. Paris.

Morton, S. G. 1830. Synopsis of the organic remains of the Ferruginous Sand Formation of the United States, with geological remarks. American Journal of Science 18, 243-250.

Mutterlose, J. 1988. Migration and evolution patterns in Upper Jurassic and Lower Cretaceous belemnites. In Wiedmann, J. \& Kullmann, J. (eds) Cephalopoda Present and Past, 525-537. Stuttgart: Schweizerbart'sche Verlagsbuchhandling.

Mutterlose, J., Schmid, F. \& Spaeth, C. 1983. Zur Paläobiogeographie von Belemniten der Unter-Kreide in NWEuropa. Zitteliana 10, 293-307.
Naef, A. 1922. Die fossilen Tintenfische. 322 pp. Jena: Verlag von Gustav Fischer.

Naidin, D. P. 1952. The Upper Cretaceous belemnites of western Ukraine. Trudy Moskovskogo Geologo-Razvedochnogo Instituta imeni S. Ordzhinikidze 27, $170 \mathrm{pp}$. [In Russian.]

Naidin, D. P. 1953. A new belemnite from the Upper Cretaceous deposits of Crimea. Byulletin Moskovskogo Obschestra Ispytateli Prirody, Otdel Geologicheskii 28, 64-65. [In Russian.]

Naidin, D. P. 1964a. Upper Cretaceous Belemnitella and Belemnella from the Russian Platform and some adjacent regions. Byulleten Moskovskogo Obschestra Ispytateli Prirody, Otdel Geologicheskii 39, 85-97. [In Russian.]

Naidin, D. P. 1964b. Upper Cretaceous belemnites of the Russian Platform and contiguous regions, Actinocamax, Gonioteuthis, Belemnellocamax. 190 pp. Moscow: Moscow University Press. [In Russian.]

Naidin, D. P. 1973. On biostratigraphical and palaeobiogeographical relation of earliest groups subdivision. Byulletin Moskovskogo Obshchestva Ispytateli Prirody, Otdel Geologicheskii 48, 50-63. [In Russian.]

Naidin, D. P. 1974. Subclass Endocochlia. Order Belemnitidae. 197-240. In Krymgol'ts, G. Ya. (ed.) Atlas of the Upper Cretaceous fauna of Donbass, 197-240. Moscow: 'Nedra' Publishing House. [In Russian.]

Naidin, D. P. 1975. Late Maastrichtian belemnitellids of Eurasia. In Menner, W.W. et al. (eds) Evolution and Change of Organic Kingdom at the Mesozoic-Caenozoic Boundary, 91-108. Moscow: 'Nauka' Publishing House. [In Russian.]

Naidin, D. P. \& Alekseev, A. S. 1975. New Neohibolites from the Cenomanian of the Crimea. Paleontologicheskii Zhurnal 3, 42-45. Moscow. [In Russian.] [Translation in Paleontological Journal 1975, 3, 311-315].

Neagu, T. \& Georgescu, D. M. 1991. Genus Belemnitella in the Campanian of Romania. Revue Roumaine du Géologie 35, 57-74.

Nikitin, I. I. 1958. Upper Cretaceous belemnites of the northeastern slope of the Dnjepr-Donetz basin. Trudy Instituta Geologicheskikh Akademia Nauk Ukrainskoi SSR, Seriya Stratigrafii i Paleontologii 20, 92 pp. [In Ukrainian.]

Nilsson, S. 1826. Om de mångrummiga snäckor som förekomma i kritformationen i Sverige. Kungliga Svenska vetenskabsakademiens handlingar 1825, 329-343.

Nowak, J. 1913. Untersuchungen über die Cephalopden der oberen Kreide in Polen. III Teil. Bulletin de l'Academie des:Sciences de Cracovie. Classe des Sciences Mathématique et Naturelles. Série B. Sciences Naturelles, for $1913,335-415$.

Obradovich, J. D. 1994. A Cretaceous time scale. In Caldwell, W. G. E \& Kaufmann, E. G. (eds) Evolution of the Western Interior Basin. Geological Association of Canada, Special Paper 39, 379-396. [Misdated 1993]

Orbigny, A. d' 1840-1842. Paléontologie française. Terrains Crétacés. 1. Céphalopodes. 1-120 (1840); 121-430 (1841); 431-662 (1842). Paris: Masson.

Owens, J. P. \& Sohl, N. F. 1973. Glauconites from New Jersey-Maryland coastal plain: their $\mathrm{K}$-Ar ages and application in stratigraphic studies. Geological Society of America Bulletin 84, 2811-2838.

Pavlow, A. P. 1914. Jurassic and Lower Cretaceous Cephalopoda of northern Siberia. Imperatovski Akademia 
Nauk, St Petersburg, Zapiski Seriia 8, Fizino-mathematicheskii 21, $68 \mathrm{pp}$. [In Russian.]

Pirrie, D. \& Marshal, J. D. 1990. High-paleolatitude Late Cretaceous paleotemperatures: New data from James Ross Island, Antarctica. Geology 18, 31-34.

Riegraf, W. 1991. Triassic belemnoids (Cephalopoda, Coleoidea) formerly described as corals, versus Tertiary corals described as belemnites (or the fairy tale of Tertiary "belemnites"). Fossil Cnidaria 20, 40-45.

Schloenbach, U. 1867. Ueber einen Belemniten aus der alpinen Kreide von Grünbach bei Wr.-Neustadt. Jahrbuch der Geologischen Reichsanstalt 17, 589-593.

Schloenbach, U. 1868. Ueber Belemnites rugifer Schloenbach sp. nov. aus dem eocänen Tuffe von Ronca. Jahrbuch der Geologischen Reichanstalt 18, 455-461.

Schlotheim, E. F. von 1813. Beiträge zur Naturgeschichte der Versteinerungen in geognostischer Hinsicht. Leonhard's Taschenbuch für die gesammte Mineralogi mit Hinsicht auf die neuesten Entdeckungen, Jahrgang 7, 134 pp.

Schlüter, C. 1874. Die Belemniten der Insel Bornholm. Zeitschrift der deutschen geologischen Gesellschaft 26, 827855.

Schlüter, C. 1894. Über die ersten Belemniten im jüngsten Pläner mit Inoceramus cuvieri. Zeitschrift der deutschen gelogischen Gesellschaft, Jahrgang 1894, 281-288.

Schmid, F. \& Schulz, M.-G. 1979. Belemnella gracilis (Archangelsky) von Adelholzen bei Siegsdorf in Oberbayern. In Wiedmann, J. (ed.) Aspekte der Kreide Europas. International Union of Geological Sciences A6, 151-158.

Schulz, M.-G. 1978. Zur Litho- und Biostratigraphie des Obercampan-Untermaastricht von Lägerdorf und Kronsmoor (SW-Holstein). Newsletters in Stratigraphy 7, 7389.

Schulz, M.-G. 1979. Morphometrisch-variationsstatistische Untersuchungen zur Phylogenie der Belemniten-Gattung Belemnella im Untermaastricht NW-Europas. Geologisches Jahrbuch A47. 157 pp.

Schulz, M.-G. 1982. Erster Nachweis der Belemnitengattung Belemnitella (B. pulchra) im mittleren Untermaastricht NW-Deutschlands. Geologisches Jahrbuch A61, 279-293.

Schulz, M.-G. 1996. Macrofossil biostratigraphy. In Schönfeld, J. \& Schulz, M.-G. (coord.) et al.: New results on biostratigraphy, palaeomagnetism, geochemistry and correlation from the standard section for the Upper Cretaceous White Chalk of northern Germany (LägerdorfKronsmoor-Hemmoor). Mitteilungen aus dem Geologisch-Paläontologischen Institut der Universität Hamburg 77, 548-550.

Schulz, M.-G., Emst, G., Ernst, H. \& Schmid, F. 1984. Coniacian to Maastrichtian stage boundaries in the standard section for the Upper Cretaceous White Chalk of NW Germany (Lägerdorf-Kronsmoor-Hemmoor): definition and proposals. Bulletin of the Geological Society of Denmark 33, 203-215.

Schulz, M.-G. \& Schmid, F. 1983a. Die Belemniten der Inoceramen-Mergel (Buntmergelserie, Ultrahelvetikum, Unter-Maastricht) des Moos-Grabens SE Siegsdorf (Oberbayern) und ihre stratigraphische Bedeutung. Zitteliana 10,653-661.

Schulz, M.-G. \& Schmid, F. 1983b. Das Ober-Maastricht von Hemmoor (N-Deutschland): Faunenzonen-Gliederung und Korrelation mit dem Ober-Maastricht von
Dänemark un Limburg. Newsletters in Stratigraphy 13, 21-39.

Schönfeld, J. \& Schulz; M.-G. (Coordinators) 1996. New results on biostratigraphy, palaeomagnetism, geochemistry and correlation from the standard section for the Upper Cretaceous white chalk of northern Germany (Lägerdorf - Kronsmoor - Hemmoor). Mitteilungen aus dem Geologisch-Paläontolischen Institut der Universität Hamburg $77,545-575$.

Seibertz, E. \& Spaeth, C. 1995. Die Kreide-belemniten von Mexico II. Belemniten des Turon Nord-Mexicos. Berliner Geowissenschaftliche Abhandlungen E16, 45-51.

Séronie-Vivien, M. 1972. Contribution a l'Etude du Sénonien en Aquitaine septentrionale. Ses stratotypes: Coniacien, Santonien, Campanien. Les Stratotype Français 2. Comite Français de Stratigraphie, 195 pp.

Skolosdrówna, S. 1932. The significance of the alveolus and alveolar fissure for the systematics of the genus $B e$ lemnitella. Posiedzenia naukowe Panstwowego institutu geologicznego 33, 117. [In Polish.]

Stevens, G. R. 1965. The Jurassic and Cretaceous belemnites of New Zealand and a review of the Jurassic and Cretceous belemnites of the Indo-Pacific region. New Zealand Geological Survey, Paleontological Bulletin 36, $283 \mathrm{pp}$.

Stolley, E. 1892. Die Kreide Schleswig-Holstein. Mitteilungen aus dem Mineralogischen Institut der Universität Kiel 1, 191-309.

Stolley, E. 1897. Ueber die Gliederung des norddeutschen und baltischen Senon sowie die dasselbe characterisierenden Belemniten. Archiv für Antropologie und Geologie Schleswig-Holsteins 2, 216-302.

Stolley, E. 1911. Beiträge zur Kenntnis der Cephalopoden der norddeutschen Unteren Kreide. I. Die Belemniten der norddeutschen unteren Kreide. 1. Die Belemniten des norddeutschen Gaults (Aptiens und Albiens). Geologische und Palaeontologische Abhandlungen, Neue Folge 10, 201-272.

Stolley, E. 1916. Neue Beiträge zur Kenntnis der norddeutschen oberen Kreide. III. Die Bedeutung der Actinocamax-Arten als Leitfossilien der oberen Kreide. Jahresbericht des Niedersächsischen geologischen Vereins zu Hannover 9, 95-104.

Stolley, E. 1919. Die Systematik der Belemniten. Jahresbericht des Niedersächsischen geologischen Vereins zu Hannover 11, 1-59.

Stolley, E. 1930. Einige Bemerkungen über die Kreide Südskandinaviens. Geologiske Föreningens i Stockholm Förhandlingar 52, 157-190.

Stoyanova-Vergilova, M \& Jolkicev, N. 1993. Representatives of the genus Belemnitella of Bulgaria (Upper Cretaceous). Geologica Balcanica 23, 25-53.

Strombeck, A. von 1861. Ueber den Gault und insbesondere die Gargas-Mergel im nordwestlichen Deutschland. Zeitschrift der deutschen geologischen Gesellschaft 13, 2060.

Surlyk, F. 1970. Die Stratigraphie des Maastricht von Dänemark und Norddeutschland aufgrund von Brachiopoden. Newsletters in Stratigraphy 1, 7-16.

Surlyk, F. \& Birkelund, T. 1977. An integrated stratigraphical study of fossil assemblages from the Maastrichtian white chalk of northwestern Europe. In Kauffman, E. G. \& Hazel, J. E. (eds) Concepts and Methods of Biostratigraphy, 257-281. Stroudsburg: Dowden, Hutchinson \& Ross, Inc. 
Ulbrich, H. 1971. Mitteilungen zur Biostratigraphie des Santon und Campan des mittleren Teils der Subherzynen Kreidemulde. Freiberger Forchungshefte C267, 47-71. Waage, K. M. 1968. The type Fox Hill Formation, Cretaceous (Maestrichtian), South Dakota. Part 1. Stratigraphy and paleoenvironments. Peabody Museum of Natural History, Yale University Bulletin 27, $175 \mathrm{pp}$.

Whiteaves, J. F. 1889. On some Cretaceous fossils from British Columbia, The North West Territory and Manitoba. Contributions to Canadian Palaeontology 1, 151196.

Whitehouse, F. W. 1924. Dimitobelidae - a new family of Cretaceous belemnites. Geological Magazine 61, 410416.

Williams, G. D. \& Stelck, C. R. 1975. Speculations on the Cretaceous palaeogeography of North America. In Caldwell, W. G. E. (ed.) The Cretaceous System in the Western Interior of North America. Geological Association of Canada Special Paper 13, 1-20.

Wright, C. W. \& Wright, E. V. 1951. A survey of the fossil Cephalopoda of the Chalk of Great Britain; Primarily a nomenclatorial revision of Daniel Sharpe's monograph (1853-57). Palaeontographical Society Monographs, 40 pp.

Zittel, K. A. von 1895. Grundzüge der Palaeontologie (Paläozoologie), 971 pp. Munich and Leipzig: R. Oldenburg. 